PERCEPTIONS OF MBA PREPARATION: NEW MASTER OF BUSINESS ADMINISTRATION GRADUATES, THEIR EMPLOYERS, AND HIGHER EDUCATION FACULTY

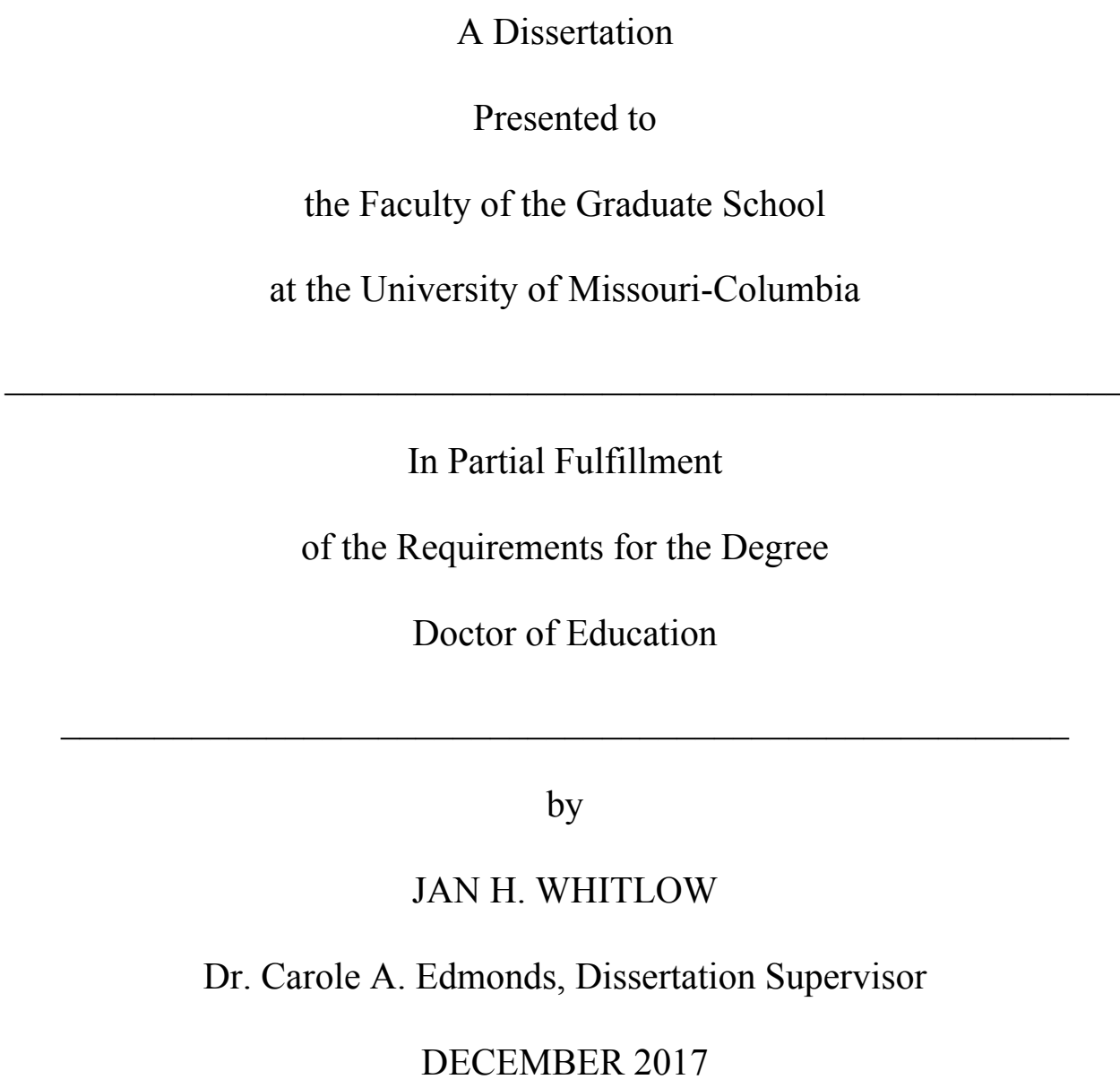


The undersigned, appointed by the dean of the Graduate School, have examined the dissertation entitled

PERCEPTIONS OF MBA PREPARATION: NEW MASTER IN BUSINESS ADMINISTRATION GRADUATES, THEIR EMPLOYERS, AND HIGHER EDUCATION FACULTY

presented by Jan H. Whitlow

a candidate for the degree of doctor of education

and hereby certify that, in their opinion, is worthy of acceptance.

Dr. Carole A. Edmonds

Dr. Timothy Wall

Dr. Gregory Rich

Dr. Victoria Seeger 


\section{ACKNOWLEDGEMENTS}

When I reflect upon this doctoral program journey through the coursework and dissertation process, there are so many people to acknowledge and express my gratitude.

- Thank you to Dr. Dean L. Hubbard for recommending the Educational Leadership and Policy Analysis doctoral program and supporting my application.

- With immense gratitude to Dr. Carole Edmonds for her tireless guidance, expertise, wisdom, and patience. You have been our continuous supporter from orientation to coursework, then to oral and written comps and finally the challenging dissertation process. Your charming smile, twinkling eyes, and encouraging sense of humor have added well placed encouragement to this journey.

- Special thanks to Dr. Timothy Wall, Dr. Gregory Rich, and Dr. Victoria Seeger for their time, willingness, and commitment to serve on my dissertation committee. Your guidance and interest in my research are very much appreciated.

- Thank you to the talented, energetic, resourceful members of the Educational Leadership and Policy Analysis Cohort Nine, for sharing this journey. I look forward to continuing our relationships and supporting each other in our endeavors.

- Thank you to the participants in my research, the students, recent graduates, faculty, and employers who invested their time and candor.

- Love and thanks to my family.

- First, to my grandparents and parents who bravely left their home countries and made significant sacrifices to come to the United States to provide opportunities for their future generations. I am living out their dreams and receiving the education they so desired. 
- Most importantly, love and thanks to my dear family Austin, Jennifer, Colleen, Kelsey, Mark, William, Ainsley, and Frances who I love more and am prouder of each day. Thank you for encouraging and supporting me and sharing this experience.

- Thank you to all the thoughtful and inspiring friends and neighbors who supported, encouraged and prayed for me during this journey.

- Finally, thank you to my loyal, loving, faithful, yellow Labrador Retriever, Luke. He was by my side for every key stroke, late night reading of another article and completion of each assignment.

I truly could not have accomplished this enormous task without all of you and I am exceedingly grateful. 


\section{TABLE OF CONTENTS}

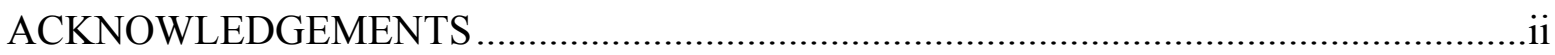

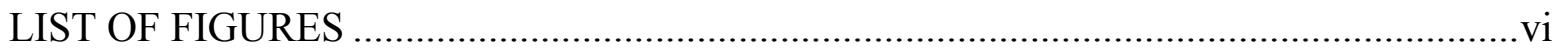

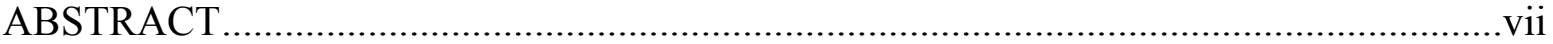

Section

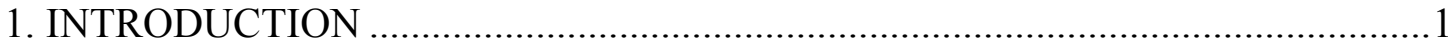

Introduction to the Background of the Study.......................................................

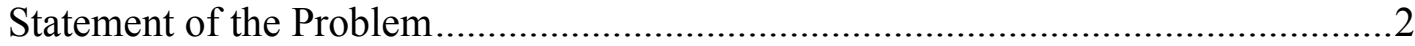

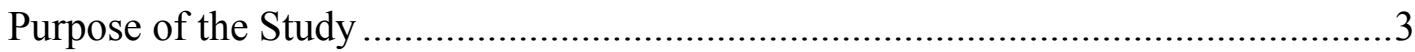

Research Questions ............................................................................................

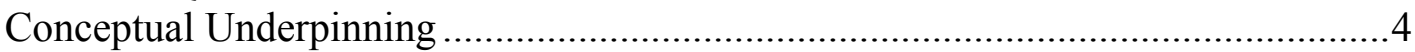

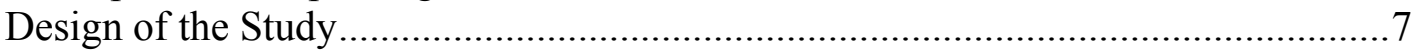

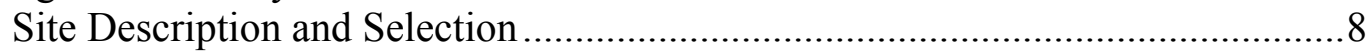

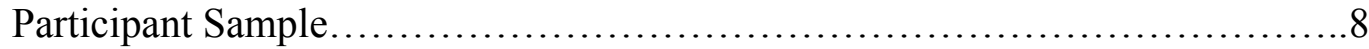



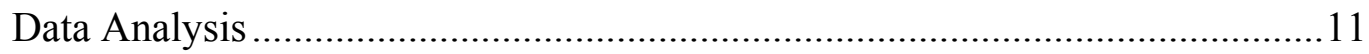

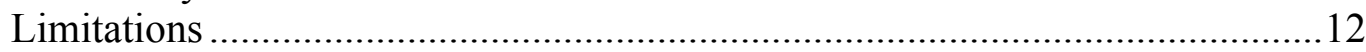

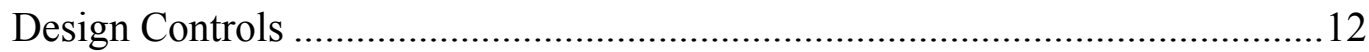

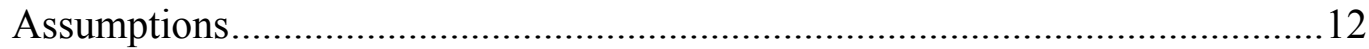

Definitions of Key Terms...............................................

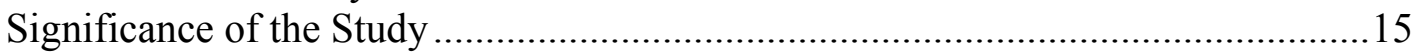

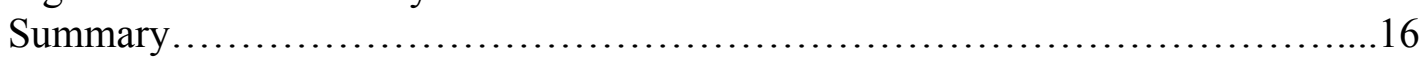

2. PRACTITIONER SETTING FOR THE STUDY ………..................................17

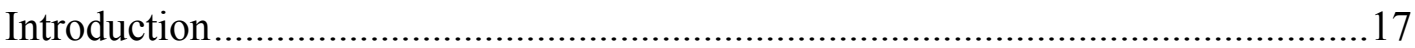

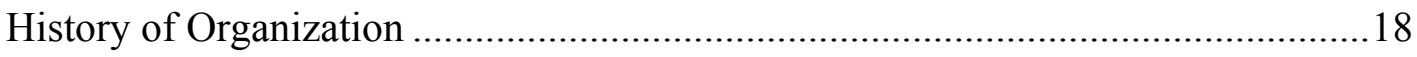

Large Midwestern University ………………………...................................17



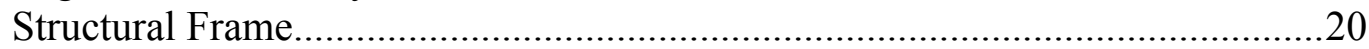

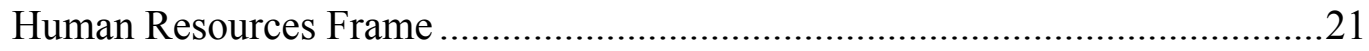

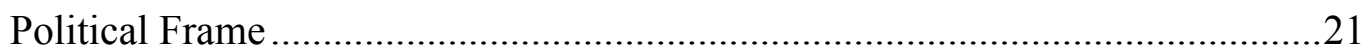

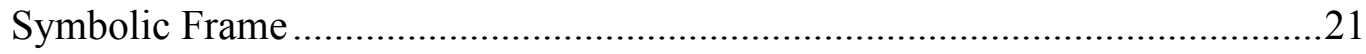

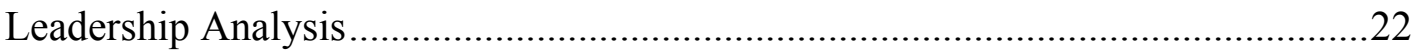

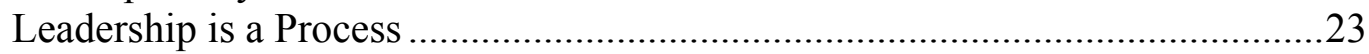

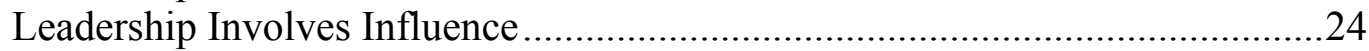

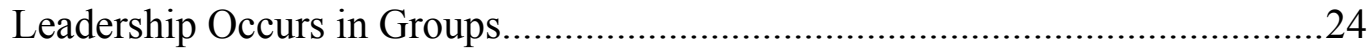

Leadership Involves Common Goals ...............................................................24

Implications for Research in the Practitioner Setting .............................................25

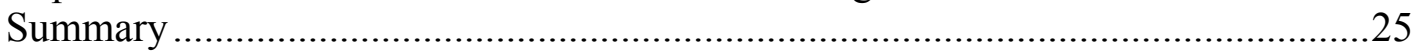

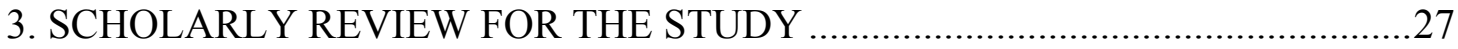




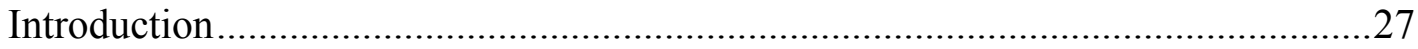

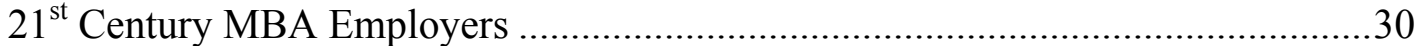

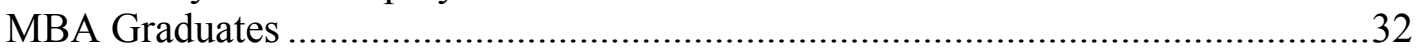

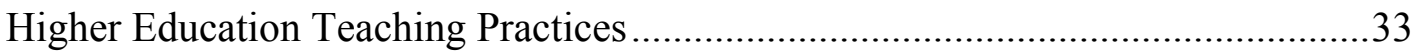

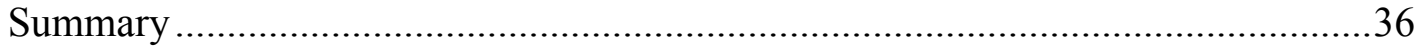

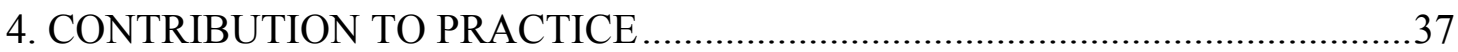

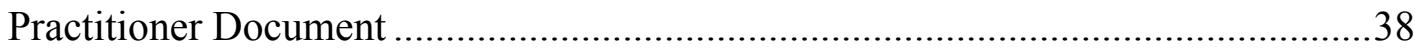

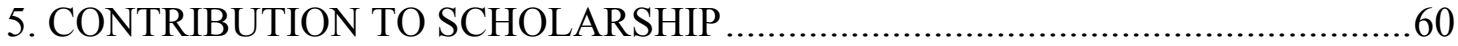



6. SCHOLARLY PRACTITIONER REFLECTION ...............................................90

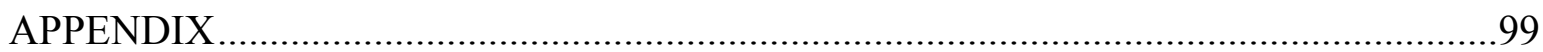

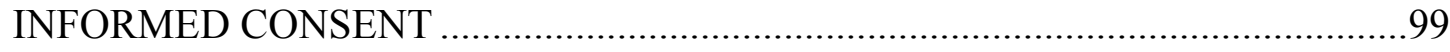

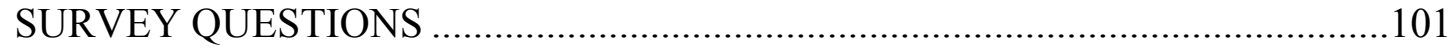

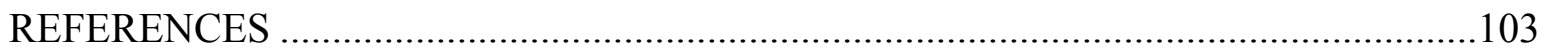

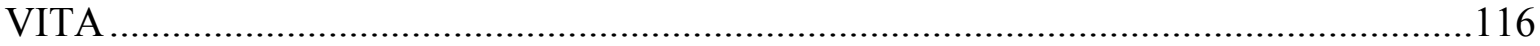




\section{LIST OF FIGURES}

\section{FIGURES}

1. Figure 1. Median annual earnings of full-time, year-round workers ages 25-34, by educational attainment: 2014

2. Figure 2. The Partnership for 21 st Century Skills Framework for 21 st Century Learning 


\begin{abstract}
This qualitative study compares perceptions of Master of Business Administration (MBA) students and recent MBA graduates with those of employers of recent MBA graduates and MBA faculty regarding the skills, competencies, and experiences needed to be successful in their new graduate jobs. The researcher gathered stakeholder perspectives of the skills, competencies and experiences needed to create successful new MBA graduates through surveys and archival data. Stakeholders included recent MBA graduates, MBA students, MBA faculty, and employers of recent MBA graduates. Analysis included MBA graduates, MBA employers, MBA faculty, and higher education practices. Results suggest that critical thinking, communication, teamwork, leadership along with data analysis are the necessary skills, competencies, and experiences needed to be successful in a recent MBA graduate position. This research further validates the extant research of DiMartino and Castaneda (2007), which indicated that the skills new job entrants most need for success in the workplace include oral and written communication, time management, critical thinking, problem solving, personal accountability, and the ability to work effectively with others. Implications of this research are to advance the academic preparation of MBA students; to improve their oral and written communications skills, critical thinking, teamwork, leadership, and data analysis.
\end{abstract}




\section{SECTION ONE}

\section{INTRODUCTION TO THE DISSERTATION-IN-PRACTICE}

\section{Background}

The importance of increasing the proportion of adults with college degrees for America to remain competitive in the global economy was a topic of President Barack Obama's first Address to the Joint Session of Congress on February 24, 2009. Veddar, Denhart and Robe (2013) wrote that a college degree is a signal of drive and talent. Those with a college degree are viewed as smarter, more intelligent, reliable and disciplined. A college education provides a ticket to an affluent middle-class life or better (Veddar, Denhart \& Robe, 2013). In 2014, the median earnings of young adults with a master's degree or higher were $\$ 59,100,18$ percent higher than young adults with a bachelor's degree (Annual Earnings of Young Adults, 2016).

\section{Figure 1. Median annual earnings of full-time, year-round workers ages 25-34, by educational attainment: 2014}

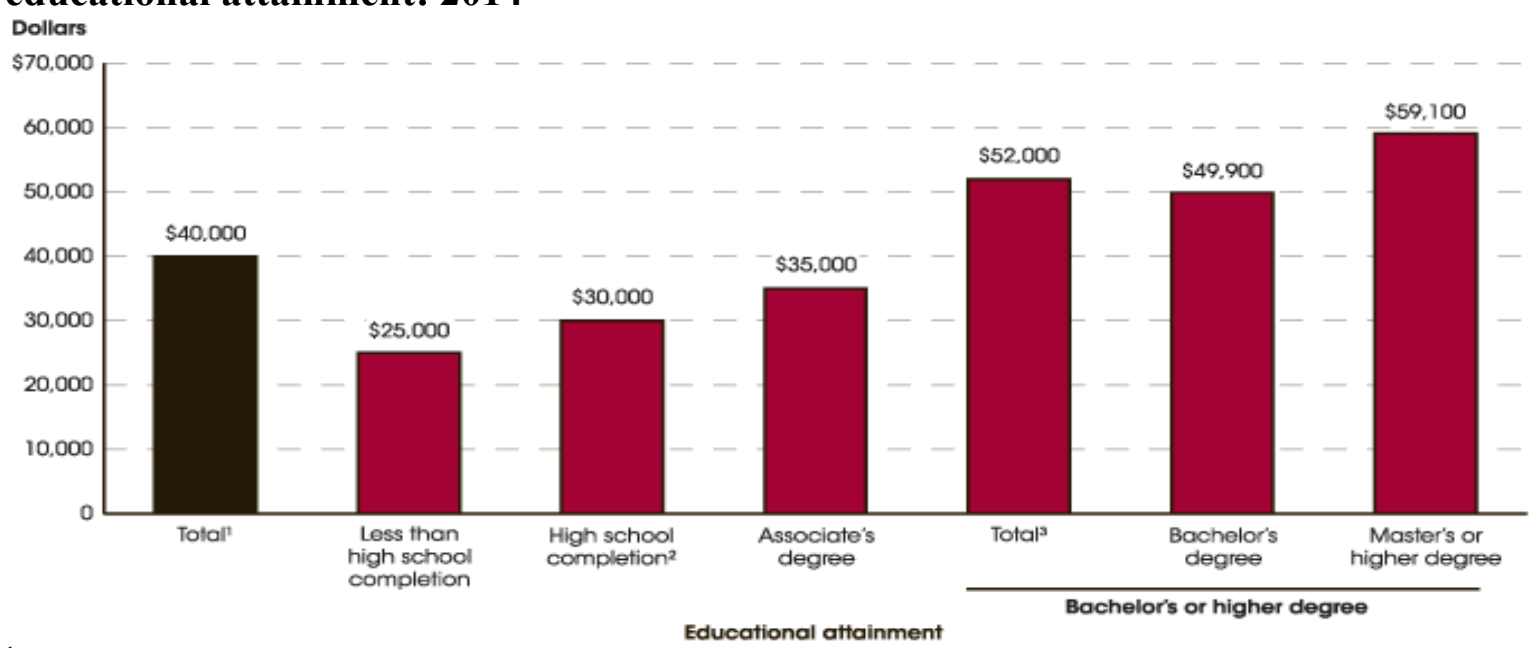

${ }^{1}$ Represents median annual earnings of all full-time, year-round workers ages 25-34.

${ }^{2}$ Includes equivalency credentials, such as the GED credential.

${ }^{3}$ Represents median annual earnings of full-time, year-round workers ages 25-34 with a bachelor's or higher degree.

NOTE: Full-time, year-round workers are those who worked 35 or more hours per week for 50 or more weeks per year.

SOURCE: U.S. Department of Commerce, Census Bureau, Current Population Survey (CPS), “Annual Social and Economic Supplement," 2015. See Digest of Education Statistics 2015, table 502.30. 
The study of business in higher education is offered at two different and distinct levels. The Bachelor of Science in Business Administration (BSBA) provides students with the opportunity to learn the fundamentals of business, while the Master of Business Administration (MBA) focuses on problem-solving orientation and enhances the student's ability to identify and implement strategies to solve business problems (Lavelle, 2012). MBA graduates are known for having specialized training in the functions of business, vocational maturity, a strong sense of career focus and values, are socialized in managerial and corporate value and possess a powerful ticket to success (Bruce, 2010; Dougherty, Dreher \& Whitely, 1993; Feldman, 2007; Veddar, Denhart \& Robe, 2013). Higher levels of management typically require an MBA.

\section{Statement of the Problem}

\section{Problem of Practice}

For the 300 students served by the traditional MBA program of this large Midwestern University, there is concern about whether they are developing the skills necessary for success in the tight competitive job market (Berdan, 2012). According to Casner-Lotto and Barrington (2006), "The future workforce is here, and it is woefully illprepared for the demands of today's (and tomorrow's) workplace" (Casner-Lotto \& Barrington, 2006, p. 9). According to the Graduate Management Aptitude Test Blog Hub, based upon a survey of 600 employers, managers want new graduate business hires to be communicators. People who can speak well, write well, listen to others, and present and sell ideas ("Employers Want Communication Skills in New Hires", 2014). Are these communication skills taught and developed as part of the 21-month MBA educational process at this large Midwestern University? Is higher education staying abreast with the 
most desirable content and fieldwork to prepare new graduates for the expectations of their future employers?

\section{Existing Gap in Literature}

Little is known about whether MBA graduates possess the skills and competencies to be successful in their new graduate job and beyond. Research by (Brown, Cober, Kane, Levy, \& Shalhoop, 2006), found there is a critical nature to the first post-graduation job, as it launches a career and leads to other opportunities. It is important to understand the skills and competencies necessary for new MBA graduates to be successful and to develop those skills during their MBA education.

\section{Purpose of the Study}

The problem under investigation is bounded by a large Midwestern University's MBA program graduates and their skills and competencies needed for success in their postgraduate jobs. According to Berdan (2012), a cross-section of the opinions of business leaders, civil servants, and academics the skills list in order of importance included communication skills, resilience, global mindset, character, quantitative, analytical and strategic thinking skills. The purpose of this study is to discover the possible gap in new knowledge for employers' perceptions of MBA graduates' skills and competencies, whether recent MBA graduates themselves believe they possess the skills and whether the curriculum provides the opportunity for students to develop the skills to be successful in their post-graduate position. The study will also examine the potential successes and challenges in the learning environment, the need for curriculum, instructional, and assessment changes, learning platforms and activities to provide the opportunity and environment for students to develop the skills employers' value. 


\section{Research Questions}

The overarching research question guiding this study is: What are the managers' perceptions of the skills, competencies, and experiences recent MBA graduates need?

Other questions guiding this study are:

1. What are the manager's perceptions of the skills, competencies, and experiences recent MBA graduates do not yet possess?

2. What are the MBA students' and recent graduates' perceptions of the skills, competencies, and experiences needed to be successful in their post-graduation job?

3. What higher education teaching practices and/or curricula are needed to effectively prepare students for their post-graduate jobs?

\section{Conceptual Framework}

The conceptual framework for this study is the Framework for $21^{\text {st }}$ Century Learning developed by the Partnership for $21^{\text {st }}$ Century Learning (P21), an organization that advocated for $21^{\text {st }}$ century readiness for every student (2011). The initiative of the Partnership for $21^{\text {st }}$ Century Learning (P21) is to provide tools and resources to help educators in the United States by integrating the core content subjects along with critical thinking, problem solving, communication, collaboration, creativity, and innovation. All are necessary skills and competencies for gainful employment in their desired occupation (Epstein, 2010). While the core content subjects including English, reading or language arts, world languages, arts, mathematics, economics, science, geography, history, government and civics, subjects commonly taught in the kindergarten thru $12^{\text {th }}$ grade education, these 
content areas and skills also apply to higher education development and learning in order to prepare students for the workforce.

According to Boyatzis (1982) one of the objectives of higher education is to prepare students to be outstanding professional managers and leaders. Additionally, Boyatzis (2007) discusses the emotional, social and cognitive intelligence competencies that predict effectiveness as a manager and leader. These competencies along with skills in communication, critical thinking, collaboration, resilience, innovation and creativity (Berden, 2011) all are needed to solve real-life problems (Gulikers, et al., 2004). The United States' national obsession with proficiency in core content is disrupting the teaching of skills graduates need for success (Dimartino \& Castaneda, 2006).

Figure 2 The Partnership for 21st Century Skills Framework for 21st Century Learning

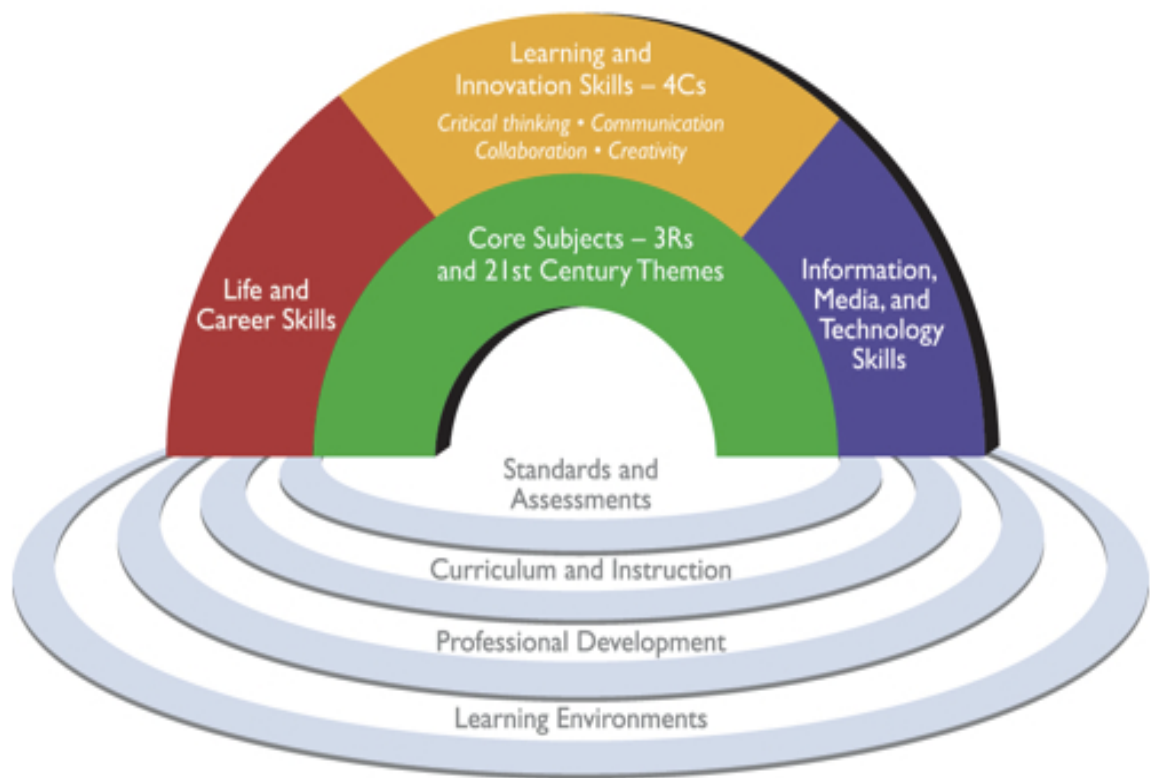

Figure 2. The four colored arches are the intended student outcomes of 21 st century learning. The four pools are the support systems needed for the outcomes to occur.

The first of the four themes defined by the Partnership for $21^{\text {st }}$ Century Skills are the core subject and $21^{\text {st }}$ century themes. The Partnership for $21^{\text {st }}$ Century Skills (2007) defines 
the core subjects as English, reading or language arts, arts, mathematics, economics, science, geography, history, and government and civics. Along with these subjects, the Partnership for $21^{\text {st }}$ Century Learning (2007) promotes the focus on moving beyond the basic competencies to an understanding of a higher level and weaving the $21^{\text {st }}$ century interdisciplinary themes into the curriculum. The themes include global awareness, financial, economic, business and entrepreneurial literacy, civic literacy, health literacy, and environmental literacy. According to (Hobson et al., 2014), appeals have occurred for restructuring of MBA programs and business school curricula to better prepare students for workplace success.

The second of the themes defined by the Partnership for $21^{\text {st }}$ Century Learning (2007) is learning and innovation skills. These skills are what separate students who are prepared for the complexity of the demands of the work environment and those who unprepared (2007). These skills include creativity and innovation, critical thinking and problem solving, and communication and collaboration skills. DiMartino and Castaneda (2007), indicate that the skills new job entrants most need for success in the workplace include oral and written communication, time management, critical thinking, problem solving, personal accountability, and the ability to work effectively with others.

The third theme identified by the Partnership for $21^{\text {st }}$ Century Learning (2007) is life and career skills. These include flexibility and adaptability, initiative and self-direction, social and cross-cultural skills, productivity and accountability, and leadership and responsibility. Business schools in the $21^{\text {st }}$ Century view learning as a process that involves both responsibility and accountability, with learning as a complex, interactive and dynamic process (Kedia \& Harveston, 1998). 
The final of the four themes is information, media and technology skills. To be successful, employees must be able to exhibit a range of functional and critical thinking skills, including information literacy, media literacy, and information, communications and technology literacy. Students and employees live in a technology and media-driven environment. Kirschner and van Merrienboer (2013), found that University students do not really have a deep knowledge of technology and what knowledge they have is limited to basic office suite skills, e-mail, text messaging, Facebook, and surfing the Internet.

\section{Design of the Study}

This case study, per Creswell (2009), is a strategy of inquiry bounded by time and activity where the researcher explores a program in depth. This study is created for educators to learn about the perceptions of employers of the skills and competencies MBA graduates should possess to be successful in their new graduate positions. Educators need to understand the skills and competencies that the new graduates are lacking and thus provide the opportunity and environment for MBA students to further develop those skills during their MBA education. According to Merriam (2009), basic, interpretive study is common in applied fields such as education and business. Basic research could ultimately inform practice; however, its primary purpose is to know more about a phenomenon (Merriam, 2009).

The basic research used will be a case study of a bounded system (Merriam, 2009). The study is searching for meaning and understanding of the competencies MBA students acquire during their MBA education and the perceptions of their new graduate managers and their ability to apply those skills and competencies. The researcher is the primary 
collector of real-life data and analysis (Merriam, 2009). Such a project lends itself to a qualitative case study.

\section{Setting}

This bounded case study includes interpreting characteristics and experiences and is a strategy of inquiry (Merriam, 2009). The MBA program at this large Midwestern University is a bounded system. A bounded system was purposefully selected due to the alignment of the $21^{\text {st }}$ century skills, knowledge, and expertise that students should master to succeed in work and life in the $21^{\text {st }}$ century along with the mission of the University to prepare students to succeed in the world of business. The site is situated in a large Midwestern city (population 108,000), according to 2016 Suburban Stats, Inc. The population is predominantly White 79\%, African American 11\%, Asian 5\%, and Hispanic or Latino 3\% (“State and county,”). The median household income is $\$ 72,913$ compared with the median income for the state $\$ 61,299$ ("State and county,"). The large Midwestern University has a student enrollment of 35,441, including 4,000 students in the College of Business undergraduates and $300 \mathrm{MBA}$ students. The student population is predominantly White 77\%, African American 7\%, Asian 2\%, and Hispanic or Latino 3\% ("Statistics and Demographics").

\section{Participants}

To fully understand the existing skills and competencies of MBA students and the perceptions of MBA new graduate managers, the researcher will use non-probability, purposeful sampling to discover, understand and gain insight Merriam (2009, p. 77-79). The researcher will also utilize the snowball form of purposeful sampling allowing participants 
will, refer the researcher to other participants that fit the established criteria (Merriam, 2009, p. 79).

The participants who are managers of recent MBA graduates (2016 and 2017), approximately $127 \mathrm{MBA}$ graduates will be selected first by referrals from the MBA career services leadership and with additional referrals from those individuals, thus the snowball

purposeful sample. The sample of managers will be surveyed to gain their insights regarding the skills and competencies necessary for new MBA graduates to be successful. Managers will represent a variety of business categories healthcare, sales, technology, marketing, logistics, research, data analysis, finance, and management.

Current MBA students and recent (2016 and 2017) MBA graduates will provide the student input and will be a convenience sample. According to Fink (2013), all MBA students will provide the sample, as they are all the students who will complete the survey.

The sample of archival documents will include syllabi for the MBA core courses Quantitative Analysis, Finance, Management, Marketing, Professional Development, and Experiential Learning. The syllabi will be used as visual, documentary materials (Merriam, 2009). These documents will be evaluated to examine the development opportunities for the Partnership for $21^{\text {st }}$ Century Skills to be enhanced in the MBA students' learning and development. Faculty teaching MBA courses will also respond to a surveyed to gain their insights regarding the skills and competencies necessary for new MBA graduates to be successful.

\section{Data Collection Tools}

The researcher is considered an insider-researcher (Drake and Heath, 2011). This researcher is a member of the large Midwestern University faculty. Being an insider, 
provides an understanding of the culture, formal and informal power structure and facilitates the research process (Unluer, 2012).

A variety of qualitative research methods will be used to identify the perceptions of the skills and competencies recent MBA graduates need to be successful in their postgraduation jobs. Triangulation will occur using multiple sources of data, increasing the internal validity of this study (Merriam, 2009). The researcher will use archival documents, syllabi for the core MBA courses Quantitative Analysis, Finance, Management, Marketing and Professional Development and Experiential Learning to assist in identifying the current learning process and opportunities. Online surveys with managers employing recent MBA graduates. MBA students and recent MBA graduates (May 2016) will complete an online survey to identify the skills and competencies they perceive as necessary to be successful in their new graduate position. Feedback was solicited for the survey questions from current a MBA student, recent MBA graduate, two employers of recent MBA graduates, and one MBA faculty member to gain insight regarding the clarity, validity and reliability of the survey questions. According to Merriam (2009), the crucial factor is not the number of surveys completed, it is the potential for each respondent to contribute to the insight and understanding of the phenomenon. Online surveys will be conducted until the saturation point is determined by the researcher.

Prior to the surveys, the researcher will obtain informed consent from all participants per the recommendations of the American Educational Research Association (Educational Researcher, 2011). The informed consent will include the purpose of the study, procedures involved in the research, all foreseeable risks and discomforts to the subject, successes of 
the research, length of time, statement of voluntary participation, as well as the participants' right to confidentiality and right to withdrawal (Fink, 2013).

\section{Data Analysis}

Once the data are gathered through the surveys and archival documents, the researcher will look for patterns and themes. Per Creswell (2009), the following steps will be used to analyze the data. The surveys will be sorted by employers of recent MBA graduates, current MBA students, recent MBA graduates, and MBA faculty. The second step is to analyze the data to get a general sense of the information and reflect on the meaning, then jot ideas in the margins to record general thoughts about the data. A list of the topics presented in the surveys will be assembled. The next step will be to begin analysis with a coding process. This step involves segmenting the data into categories and labeling the categories with a term. Each category will be color coded. The color-coded data will be sorted by theme and grouped for review. The researcher will then take the list of terms and review the data, labeling the content with the code for each term or theme. Then the data for each category will be assembled. The codes will emerge through the data analysis (Merriam, 2009).

The archival documents including course syllabi and student assignments and evaluations will be assessed to determine if the skills and competencies identified by the employers of new MBA graduates are being developed. According to Merriam (2009), a qualitative study of classroom instruction will include documents such as instructors' lesson plans and student assignments. The data analysis of the course syllabi will follow the same steps as the survey data including reading the syllabi, identifying the activities, assignments, readings and discussion that develop the skills employers perceive as beneficial, segmenting 
the data into categories and labeling the categories with a term, sorting and assembling the data by category for analysis.

\section{Limitations, Assumptions, and Design Controls}

This case study focuses on one MBA program, and is not expected to be nationally generalized. Qualitative case studies are also limited by the sensitivity and integrity of the researcher (Merriam, 2009). Other limitations of qualitative research involve the issues of reliability, validity, and biases. (Merriam, 2009). Case studies account for and include difference, and most importantly the humanly side of research (Merriam, 2009, p. 52). The case study is limited by time. It is a snapshot of the conditions occurring at the time the surveys are conducted and the semester the syllabi represent and are evaluated.

Case studies have natural boundaries and parameters (Merriam, 2009). This case study focuses on a single, large Midwestern University full-time MBA program. Only stakeholders who employ recent MBA graduates will be surveyed, current MBA students will be surveyed and MBA program syllabi will be analyzed.

Along with limitations and delimitations, there are also assumptions, including that the responses to the questions are truthful and the sample represents the entire MBA student population and MBA new graduate employers. To assure the reader that the study will get to the heart of the research questions, the survey questions will be pilot tested and revised. The reader will also be assured that the MBA program is sustainable by the enrollment figures and the literature review of the importance of an MBA education and job opportunities available for MBA graduates. 


\section{Definition of Key Terms}

Master of Business Administration. The traditional MBA program begins in the fall semester and includes adjacent spring semester, break for the summer and concludes with the following fall and spring semesters with a May graduation. Thus, the course of study is 21 months, with an internship during the summer between the second and third semesters (MBA, 2016).

Bachelor of Science in Business Administration. The undergraduate Bachelor of Science in Business Administration degree includes general education as well as specialized courses focused specifically on business-related coursework (Uyeno, n.d.).

Competencies. Observable and measurable knowledge, skill, capability or ability, attributes that contribute to performance. The quality of being able to perform. A quality that contributes to and facilitates achievement, accomplishment and performance (Boyatzis, 2007). Competencies provide the how. How employees behave in a work environment to achieve a desired result ("What's the difference between skills and competencies", 2016). Demonstration of knowledge, skills, behaviors, and attitudes acquired from a role (Harris \& Hodges, 1995).

Credentials. Indication that the applicant is qualified for the position, work or academic program. It is a qualification, achievement, experience, or personal quality that indicates a level of knowledge, experience or accomplishment (dictionary.com, 2017).

Critical Thinking. Making clear reasoned judgments. Ideas are well thought out, information is gathered, analyzed, and evaluated, and used as a guide to beliefs and actions (Ennis, 2002). For this study the definition of critical thinking is to gather information, 
understand and evaluate theories, connect information and theories to reach a decision and develop a plan to take action on that decision.

Curriculum. A course of study in one subject or a list of all course of study by a college or school. It includes a program or plan of activities (dictionary.com, 2017).

Experience. Learning acquired in everyday situations or workplace/job settings (Harris \& Hodges, 1995).

GED or HiSet exams. Tests to determine the level of knowledge to receive a high school education. Skills and knowledge are measured in five core areas language arts reading and writing, mathematics, science and social studies.

Organizational Socialization. Process of adaptation, learning, skill development, behavior that a new employee goes through to engage in a new organizational culture, to become an effective member, an insider. It is the transformation from organizational outsider to a participating and effective employee (Feldman, 1976).

The Partnership for $\mathbf{2 1}^{\text {st }}$ Century Skills (2007) defines $21^{\text {st }}$ Century Learning Skills as the core subjects English, reading or language arts, arts, mathematics, economics, science, geography, history, and government and civics. Along with these subjects, the Partnership for $21^{\text {st }}$ Century Learning (2007) promotes the focus on moving beyond the basic competencies to an understanding of a higher level and weaving the $21^{\text {st }}$ century interdisciplinary themes into the curriculum. The themes include global awareness, financial, economic, business and entrepreneurial literacy, civic literacy, health literacy, and environmental literacy. 
Perception. An awareness, impression, idea, observation, understanding, sense, that is formed about an idea, occurrence, event, person, performance that is formulated with careful mental thought (dictionary.com, 2017).

Post-graduate or Recent Graduate. Person who completed a college degree in the past two years (Jusoh, Simun and Chong, 2011).

Skill. Skills are specific learned activities such as "mopping the floor" or "performing brain surgery". Skills provide the what (dictionary.com, 2017). The specific abilities a person possesses to perform a specific job ("What's the difference between skills and competencies", 2016). An acquired ability to perform well; an act requiring a high degree of competence (Harris \& Hodges, 1995).

\section{Significance of the Study}

\section{Practice}

This research will identify the skills, competencies, and experiences new MBA graduate employers recommend students develop and exhibit. It will invite, encourage, and challenge higher education to make changes, take risks, evaluate, change learning environments, and create opportunities for MBA students to develop the skills and competencies needed to be successful in their post-graduate jobs. This research will suggest the roles that can be displayed by employers, recent graduates and higher education to reduce the gaps between recent graduates' capacity and the expectations of their employers.

\section{Scholarship}

New MBA graduates are entering a tight, competitive job market (Berdan, 2014). Little is known about whether MBA graduates possess the skills and competencies to be 
successful in their new graduate jobs and beyond, Brown et al (2006). Higher education is responsible for preparing students for the job market (Epstein, 2010).

\section{Summary}

Earning an MBA provides students with the opportunity to improve their standard of living, advance their careers, develop new skills and knowledge to make insightful and accurate decisions, and secure more challenging and fulfilling job positions. According to Zabid and Ling (2003), the key skills and competencies MBA hiring managers are seeking, include decision-making ability, written communication, oral communication, analytical skills and interpersonal skills. All skills their research found to be lacking in recent MBA graduates (Zabid \& Ling, 2003). Completing surveys and studying archival documents, the researcher will gather the qualitative data necessary to determine the skills and competencies MBA graduates should develop to be successful in their new graduate job assignments. This research will provide the data and evaluation to improve the content

presentation and assessment for the MBA program at a large Midwestern University and better prepare MBA graduates for their new graduate positions. 


\section{SECTION TWO}

\section{PRACTITIONER SETTING FOR THE STUDY}

The large Midwestern University Master in Business Administration (MBA) Program strategic plan includes a commitment to improve the U.S. News and World Report MBA ranking for public institutions by advancing the large Midwestern University College of Business-MBA Program upward (improvement) by ten positions in five years. The strategic plan includes commitments for improvements in admissions, curriculum, and placement. Specific improvements include:

Admissions

- Identifying talent for potential future enrollment early

- Identifying potential future enrollment talent where talent is most competitive

- Promoting the value of the MBA program

Curriculum

- Developing professional certifications and campus partnerships

- Developing leadership and career development

- Implementing experiential learning

Placement

- Developing corporate engagement initiatives

- Career coaching and management development

- Salary and placement initiatives

The purpose and the strength of the program include that the MBA program is personal, flexible and affordable. Top talent will be attracted to the MBA program through 
the centers of strength marketing analytics, finance, entrepreneurship and innovation (MBA Strategic Plan, 2016).

\section{History of the Organization}

\section{Large Midwestern University}

In 1839, 900 citizens of the county where the large Midwestern University resides pledged $\$ 117,921$ in cash and land to bid for the location of the new university, the first public university west of the Mississippi (Large Midwestern University, 2016). Growth and expansion of the university began in 1870 , with the award of the land-grant status and the College of Agriculture, Food and Natural Resources along with the "Normal College", now the College of Education. Other early college additions included journalism, law and medicine, along with the graduate school in 1896 (Large Midwestern University, 2016). The College of Business founded in 1914, along with the university becoming a major research institution.

The university was a single campus until 1870 with the addition of a School of Mines and Metallurgy. Further expansion occurred in 1963, when the university expanded to serve the entire state by founding a four-campus University System (Large Midwestern University, 2016). The mission of the University system, as a land-grant university and the only public research and doctoral-level institution, is to discover, disseminate, preserve, and apply knowledge. The university promotes learning by its students and lifelong learning by state citizens, fosters innovation to support economic development, and advances the health, cultural, and social interests of the people of the state, the nation and the world and serves over 77,000 students (Large Midwestern University, 2016). 
The large Midwestern University serving as the sample for this research is largest of the educational institutions within the university system. It serves over 35,000 students (Large Midwestern University, 2016). Founded in 1914, the College of Business serves over 5,500 students preparing for responsibilities in business and government along with offering PhD degrees in business fields (Large Midwestern University, 2016). In 1964, the MBA program serving as the sample for this research was founded. Additionally, in 2012, the execMBA program launched (Large Midwestern University, 2016).

The university system is governed by a Board of Curators, while the Office of the President provides overall leadership, vision and direction for the University System. The president is responsible for all faculty and other university employees, academic, public, business, financial and related affairs of the university system. The University System, a land-grant research institution, includes four diverse campuses located in four large metropolitan cities and includes a health care system and statewide extension mission (Large Midwestern University, 2016). The Board of Curators gave general delegation of authority to the president to act on behalf of the Board subject to the bylaws, board rules and specific instructions of the board (Large Midwestern University, 2016). The Office of General Counsel provides all legal representation. The Office of the Secretary provides transcription for all meetings of the board, acts as custodian of the seal and all board and university records (Large Midwestern University, 2016).

Founded in 1870, the large Midwestern University is today one of four universities in a large university system. The MBA program is part of the College of Business, serving over 5,500 students with the MBA program serving 120 students. Founded in 1964, the 
MBA program provides students with the opportunity to develop specialized skill sets, improve their leadership skills, analytical skills, interpersonal and managerial skills.

\section{Organizational Analysis}

Organizations are complex and ambiguous, making them a challenge to manage (Bolman \& Deal, 2008). Clear, well-defined goals, roles, relationships are vital to organizational performance (Bolman \& Deal, 2008). This analysis describes the large Midwestern University's organization through the structural, human resources, political and symbolic frames or lenses that affect how people see each other and how they work together (Bolman \& Deal, 2008). Understanding that organizations consist of individual people and groups of people all influencing the productivity of the organization. Leaders must use more than one lens or frame in order to understand and manage organizations (Bolman \& Deal, 2008).

\section{Structural Frame}

The structural frame deals with the rules, goals, and policies that influence decisions and behaviors (Bolman \& Deal, 2008). The leadership, faculty and staff of the MBA program are influenced by the leadership, policies, rules and environment of the university system, large Midwestern University, College of Business and MBA program structural frame. Policies exist to provide guidance, direction, restrictions and parameters for admissions, curriculum, faculty selection and promotion, student progression within the program, and expected outcomes. The structural frame influences the process for decision making, setting priorities, coordination of individual and group activities. 


\section{Human Resources Frame}

The human resources frame is the lens to examine the people as the heart of the organization to help gain commitment and loyalty (Bolman \& Deal, 2008). The organization is tailored to fit the individual needs. The organization of the MBA program includes an Assistant Dean, Director of the Executive MBA program, Director of Admissions, Director of Advising and Director of Career Services along with the staff that support each of these functional areas.

\section{Political Frame}

Bargaining, negotiation, coalition building, allocation of scarce resources are all part of working with stakeholders to achieve goals and objectives (Bolman \& Deal, 2008). The MBA Assistant Dean understands how decisions are made and the organizational structure within the College of Business, large Midwestern University and the university system, all influencing how he negotiates differences and determines reasonable comprises. Allocation of resources for program expansion, faculty hiring, travel to develop partnerships with employers, training for faculty and staff, all investments requiring resources. Securing these resources requires negotiation and building power bases and using power wisely (Bolman \& Deal, 2008).

\section{Symbolic Frame}

The symbolic frame promotes a common vision and culture including rituals, ceremonies and events all to make people feel important (Bolman \& Deal, 2008). Culture is a process and the leader's job is to inspire. The large Midwestern University is steeped in tradition with signs, processes, campus events, communications and relationships to provide a sense of cohesiveness and meaning. Each new MBA cohort starts the academic program in 
the fall semester with events, group work, contests and activities all long-standing practices to provide a sense of inclusion.

The large Midwestern University organization is complex and must respond to the needs, goals and objectives of the workforce that employs the MBA graduates along with the university system, large Midwestern University, and College of Business. In order to achieve these objectives and improve the ranking of the MBA program, an understanding of how decisions are made and resources allocated through each of the four frames: structural, political, human resources and symbolic. Understanding the organization is important for establishing decision processes, however, understanding the leadership is as beneficial for managing the capacity to make things happen.

Leadership of the large Midwestern University system includes a System President who receives guidance from and is held accountable to, the University Board of Curators (Large Midwestern University, 2016). The university system president along with the campus Chancellor and the Dean of the College of Business for the large Midwestern University that houses the College of Business and MBA program, all are consistently checking for results against expectations (Drucker, 2011). Thus, the leadership structure includes the University System President, large Midwestern University Chancellor, Dean of the College of Business and the MBA Assistant Dean, all are part of the community of teaching, learning and serving to develop students into engaged, compassionate and responsible citizens (Large Midwestern University, 2016).

\section{Leadership Analysis}

Leadership means many different things to many different people (Northouse, 2013). Northouse (2013) defines leadership as "a process whereby an individual influences a group 
of individuals to achieve a common goal" (Northouse, 2013, p. 5). Leadership is a transformational event that occurs between the leader and the followers (Northouse, 2013, p. 5). The following leadership analysis discusses Northouse's (2013) four basic leadership components, leadership is a process, leadership involves influence, leadership occurs in groups, and leadership involves common goals (p. 5).

\section{Leadership is a Process}

Northouse (2013) defines the process of leadership as an exchange in which leaders are affected by followers and followers are affected by leaders. Leadership is a process involving how an individual influences other toward a goal or objective (Northouse, 2013). The current MBA Assistant Dean was new to the position in 2016, replacing a Dean with 20 years of leadership in the Assistant Dean position. The transformational process of the leadership change was an interactive event. The new Assistant Dean created an atmosphere and work culture where all staff and faculty were part of the process. The commitment of the team to develop a strategic plan and budget outlining the resources needed to make the strategic changes was not restricted to the leader. The MBA program leadership team including the Director of the Executive MBA program, Director of Admissions, Director of Advising and Director of Career Services along with their staff were involved in the development and implementation of the strategy plan. There is a commitment of the leader to help the followers (direct reports and staff) achieve to their potential (Northouse, 2013). This transformational process is led by a leader with charismatic leadership as he sets a strong role model, shows competence, articulates goals, communicates high expectations and expresses confidence in the transformational process and the staff and faculty (Northouse, 2013). 


\section{Leadership Involves Influence}

The leader is the center of change and activity with the ability to influence others to accomplish tasks, often greater than what is expected of them (Northouse, 2013). "The MBA Assistant Dean leads by example and is committed to inspire others to be committed to provide an excellent educational opportunity for the students"(J. Whitlow, personal communication, July 27, 2016). "He listened and learned to gain an understanding of the culture, history, hot buttons, what worked in the past and what did not" (J. Whitlow, personal communication, July 27, 2016). As a leader, the Assistant Dean is authentic as he focuses on what is genuine and real; he strives to do what is right (Northouse, 2013).

\section{Leadership Occurs in Groups}

The MBA Assistant Dean assumes the leadership role along with his direct reports and their staffs. The development of the 2016 strategic plan included many stakeholders, the College of Business leadership, university and system leadership and the Directors within the MBA program leadership, Director of the Executive MBA, Director of Admissions, Director of Advising, and Director of Career Services.

Leaders rely on others to raise questions that may indicate the need for change (Heifetz \& Laurie, 2011). According to Levi (2008), members of teams are empowered and work effectively to accomplish goals. Each group was given the clear objective to develop a plan to improve the MBA program ranking in the US News and World Report ranking by ten positions by 2021. Teams were formed to develop plans for placement, admissions, curriculum, and peer assessment, all efforts to improve the program's ranking position by ten positions by 2021. The teams bring together varied and diverse skills and competencies, perspectives, and experience to make better decisions (Levi, 2008). The objectives are too 
complex for individuals to solve on their own and require the expertise of the group to effectively solve the problem (Levi, 2008).

\section{Leadership Involves Common Goals}

The goal of the Assistant MBA Dean is clear; improve the program ranking by ten positions by 2021. High-performing teams transform common purpose into specific, measurable performance goals (Bolman \& Deal, 2008). These teams developed a common commitment to a working relationship and held themselves accountable (Bolman \& Deal, 2008).

As a transformational leader, the Assistant MBA Dean motivated followers to do more than expected (Northhouse, 2013). The Assistant MBA Dean, a transformational leader, plays a pivotal role to influence change (Northhouse, 2013). Transformational leadership is the process "whereby a person engages with others and creates a connection that raises the level of motivation and morality in both the leader and the follower" (Northouse, 2013, p. 186).

\section{Implications for Research in the Practitioner Setting}

Understanding the skills, competencies and experiences employers desire in new MBA graduates will provide direction for further development of the curriculum and internship opportunities to develop those skill, competencies and experiences. The purpose of this study is to discover the possible gap in new knowledge between employers' perceptions of MBA graduates' skills and competencies, whether recent MBA graduates themselves believe they possess the skills and whether the curriculum provides the opportunity for students to develop the skills to be successful in their post-graduate position. The study will also examine the successes and challenges in the learning environment, the 
need for curriculum and instructional changes, learning platforms and activities to provide the opportunity and environment for students to develop the skills employers' value.

\section{Summary}

Understanding the history, organizational structure and leadership of the large Midwestern University and the MBA program in which this study takes place will provide input for changes in the curriculum, admissions, advisement and career services. The analysis of data provided by surveys with employers of MBA graduates, survey analysis from current MBA students and recent MBA graduates, along with archival data focusing on the course and learning objectives will support the $21^{\text {st }}$ Century Learning Skills Framework life and career goals, learning and innovation skills, information and technology skills and core subject themes. Good leaders focus on opportunities, using knowledge and evidence from the gap between what is and what could be (Drucker, 2011). 


\section{SECTION THREE \\ SCHOLARLY REVIEW}

Higher education is responsible for preparing students for the job market (Epstein, 2010). Students need to be prepared for gainful employment in the field or the occupation studied, occupations requiring an education to secure, that pay enough to afford the opportunity to repay student loans (Epstein, 2010). A college degree is a signal of drive and talent and indicates a person is smarter, more intelligent, reliable and disciplined and provides a ticket to an affluent middle-class life or better (Veddar, Denhart \& Robe, 2013).

As part of career advancement and the pursuit of a meaningful career that offers long-term advancement and personal satisfaction, individuals chose to enroll in a Master of Business Administration MBA programs (Muja \& Appelbaum, 2012). Casner-Lotto and Barrington (2006), suggest MBA graduates are ill-prepared for the demands of the current and future work environment. New job entrants need oral and written communication skills, time management, critical thinking, problem solving, personal accountability, and the ability to work effectively with others (DiMartino \& Castaneda, 2007).

The initiative of the Partnership for $21^{\text {st }}$ Century Learning is to provide the tools and resources to help educators in the United States by integrating the core content subjects along with critical thinking, problem solving, communication, collaboration, creativity, and innovation. Whether these skills and competencies are present in MBA graduates will be researched through the lenses of $21^{\text {st }}$ Century Learning student outcomes. While these skills are recognized by the Partnership for $21^{\text {st }}$ Century Learning, are they recognized by employers, MBA students and recent MBA graduates? Is the development of these skills 
incorporated into the MBA curriculum and assessment to help prepare MBA graduates for the workforce?

The Partnership for $21^{\text {st }}$ Century Learning (P21 Framework, 2015) developed a unified vision and framework that describes the skills, knowledge, and expertise students need to succeed in work and life. Students build from the base of academic subject knowledge and think critically and communicate effectively to be successful in work and life (P21 Framework, 2015). Themes for student outcomes include mastery of the key subjects and $21^{\text {st }}$ century themes global awareness, financial, economic, business and entrepreneurial literacy, civic literacy, health literacy and environmental literacy (P21 Framework, 2015). Student outcomes also include learning and innovation skills, creativity and innovation, critical thinking and problem solving, along with communication and collaboration (P21 Framework, 2015). Finally, information, media, and technology skills and life and career skills complete the unified vision and framework for $21^{\text {st }}$ century learning.

Business managers face intense competition and need employees who are prepared to be competent business leaders of the $21{ }^{\text {st }}$ Century (Kedia \& Harveston, 1998). Students need a holistic approach to teaching and learning so they view business problems in their entirety from analysis, using the mastery of key academic subject area content to implementation (Kedia \& Harveston, 1998). According to Lee and Hung, $21^{\text {st }}$ Century learning is about the interactions between theory and practice. By combining individuals and business, formal and informal learning, the tacit knowledge is formed and becomes useful in practice. Learners are equipped with content knowledge of traditional disciplines such as finance, technology, management, statistics and need to be aligned with business 
problems and applications (Lee \& Hung, 2012). In their study of $21^{\text {st }}$ century workforce skills, DiMartino and Castaneda (2007) find that in the national obsession with core content expertise there is a distraction from the skills students need for success, critical thinking, collaboration, and communication skills.

Learning and innovation skills are what prepare students for the work environment in today's world (P21 Framework, 2015). These skills including emotional and social intelligence can be developed in graduate management programs (Boyatzis, 2008). MBA students benefit from problem solving cases that require teamwork along with feedback from professors, to improve their leadership and teamwork skills (Hobson, Strupeck, Griffin, Szostek \& Rominger, 2014). Employers of MBA graduates are looking for graduates with business experience who can solve problems and demonstrate they can use critical thinking, collaboration and communication skills (Neeley \& Tucker, 2012).

In order to navigate complex life and work environments, today's students need to develop life and career skills including thinking skills, content knowledge, and social and emotional competencies (P21 Framework, 2015). Students enhance skills such as team bonding, developing refinement strategies while the work is in progress, filtering critical information, and making the best of a situation through the use of multiple life and career skills (Shaari \& Lee, 2012). Real life requires the ability to integrate and filter knowledge, experience, skills, attitudes, along with emotional, social and cognitive intelligence and the ability to apply them to new and challenging problems and situations (Gulikers, Bastiaens \& Kirschner, 2004; Boyatzis, 2008).

Today's work place is a technology and media-driven environment and requires access to a wealth of information with rapid changes in technology and the need to 
collaborate to keep abreast of changes (P21 Framework, 2015). Employers value technical skills and knowledge of database management, resourcefulness, data search skills and integration of complex information and data (Gabric \& McFadden, 2000). University students entering the workforce need to have a comprehensive knowledge of technology and an understanding of how technology supports problem solving by going beyond basic office suite skills, e-mailing, text messaging, Facebook and surfing the Internet (Kirschner \& Van Merrienboer, 2013; Darling-Hammond \& Snyder, 1999).

\section{$21^{\text {st }}$ Century MBA Employers}

The Partnership for 21st Century Learning (P21) describes the skills, knowledge and expertise students should exhibit to be successful in work and life (2011). These skills including critical thinking, communication, and creativity are also recognized by employers of recent MBA graduates as marketable skills necessary for success (Berdan, 2012). Little research focuses on the link between the business community and students (Gabric \& McFadden, 2000). Clear differences exist between the skills needed by the business community and the skills acquired by the students (Gabric \& McFadden, 2000). According to Boyatzis and Sokol (1982) and Porter and McKibbin (1988), MBA programs predominantly improve students' analytical skills. The reasons recent graduates remain unemployed, were poor communication and problem-solving skills, lack of industrial training exposure, bad attitudes and lack of self-confidence (Wong, 2010). The future workforce is woefully ill-prepared for the demands of the workforce (Casner-Lotto \& Barrington, 2006)

The skills job entrants most need for success in the workplace include oral and written communication, time management, critical thinking, problem solving, personal 
accountability, and the ability to work effectively with others, however, all skills the graduates evaluated in a recent study conducted by the Partnership for $21^{\text {st }}$ Century Skills and three other organizations were lacking (DiMartino \& Castaneda, 2007). The study surveyed 400 employers across the United States regarding the workforce readiness of high school and college graduates. This research found that the skills new job entrants most need for success in the workplace, are the skills the graduates are least prepared to demonstrate (DiMartino \& Castaneda, 2007). Emphasis is needed on skills, such as self-confidence, selfmotivation, resilience, and adaptability (DiMartino \& Castaneda, 2007).

Gabric and McFadden (2000) found a significant difference between employers', 2003 and students' perceptions of the importance of the critical skills necessary for successful employment. Three categories emerged qualitative, quantitative, and personal attributes. Qualitative or general business skills included working in teams, problemsolving, handling ambiguous situations, and effective communications (Gabric \& McFadden, 2000). Quantitative skills or technical skills included analytical skills, programming, database management (Gabric \& McFadden, 2000). Personal attributes include being conscientious, motivated, and ethical (Gabric \& McFadden, 2000). According to the Graduate Management Aptitude Test Blog Hub, based upon a survey of 600 employers, managers want new graduate business hires to be communicators. People who can speak well, write well, listen to others, and present and sell ideas ("Employers Want Communication Skills in New Hires", 2014). Managers assume MBA candidates have core business knowledge, strong analytical skills, quantitative and technical skills. However, the top four skills managers require in new business graduates are communication-related skills, including oral and listening skills, written communication, 
presentation skills, and teamwork ("Employers Want Communication Skills in New Hires", 2014). Managers expect MBA graduates to be the future, strong, effective, leaders of their organizations and with that expectation, desire their new MBA graduates to possess not only the technical skills, along with strong communication and interpersonal skills ("Employers Want Communication Skills in New Hires”, 2014).

Managers assume recent graduates are knowledgeable and capable of performing their work independently and are surprised when the recent graduates need more performance feedback and a more structured work environment (Jusoh, Simun and Chong, 2011). The academic methods of performance feedback leave the students unprepared for the expectations of the work environment (Jusoh, Simun and Chong, 2011). Recent graduates are also seen as too theoretical, naïve, and idealistic, along with immature and inexperienced (Shein, 1964; Holton, 1992).

\section{MBA Graduates}

Little research has examined the expectations of new business graduates, their knowledge of post-graduate job expectations and demands, and the preparation to meet those demands and expectations (Garavan \& Morley, 1997). MBA students believe having an MBA is a means of developing a multidisciplinary and broad functional knowledge that is relevant in many industries. It is a "ticket" to increased salary and senior management (Muja \& Appelbaum, 2012). College graduates enter the workforce with expectations, mainly based on what they have been taught, that they will obtain satisfied, secure, and well-paying employment (Shelley, 1994). MBA students expect to receive achievement, recognition, responsibility, and advancement with their degree (Muja \& Appelbaum, 2012). 
Cognitive skills and motivation will drive their post-graduation job success, are the beliefs of MBA students (Holton \& Russell, 1997).

Students enter MBA programs intending to develop their leadership skills, increase their earnings, and experience the real-world by interacting with executives and professors. MBA students achieve this knowledge and experience through classes, cases and community service. The MBA program at this large Midwestern University is nationally recognized and AACSB accredited (MBA Strategic Plan, 2016). The two-year, full time, 57 (including 22 credit hours of electives) credit hour program includes 120 students, $44 \%$ are female, 35\% international, and 7\% minority (Admission, 2016). Most students, $80 \%$ enter with a Graduate Management Admissions GMAT score of 600-670 and an undergraduate GPA of 3.5 or higher (Admission, 2016.) While previous courses in accounting, finance and statistics are helpful, students are admitted from any undergraduate program (Admission, 2016).

The academic work focuses on building a customized curriculum and professional development program to prepare students for a successful career. The first year of the MBA program includes strong foundational courses in Data Analysis, Managerial Marketing, Microeconomics for Business, Finance, Organizational Behavior, Management Information Systems, Operations Strategy, and Statistics. The second-year curriculum includes, Financial Statement Analysis, Ethics and Leadership, Strategic Global Competitiveness and elective courses in Finance, Management or Marketing.

\section{Higher Education Teaching Practices and Curricula}

In between employers and college graduates are universities whose role is to prepare graduates for the competitive job market (Sewell \& Pool, 2010). Universities are under 
pressure from parents, students, and the business community to prepare students to be productive employees, good citizens, and dedicated, responsible, knowledgeable professionals (Heitkemper, 1998). Holton (1992) emphasized after interviewing hundreds of new employees, managers and executives that although universities had excelled at teaching technical skills, too little attention is placed on teaching graduates how to go to work. Universities play a major role in preparing the expectations of new graduates (Garavan \& Morley, 1997).

Universities should regularly revise and develop academic programs to better prepare students for the jobs of tomorrow (Gabric \& McFadden, 2000). Research suggests redirecting instruction to a more balanced approach to focus on core content knowledge and applied skills (knowledge, work habits, and character traits) with feedback provided through authentic assessment (Darling-Hammond, Rustique-Forrester, \& Pecheone, 2005; Herman, 1997; Wiggins, 1990). Authentic assessments require students to use prior knowledge, recent learning, and relevant learning to solve complex problems (DiMartino \& Castaneda, 2007).

Improved communication between employers and MBA academic leadership will aid in the development of human capital and improve workforce efficiency (Muja \& Appelbaum, 2012). Understanding the trends and receiving feedback from the business community will allow business schools to improve their curriculum and assessment and better prepare students for the workplace demands and objectives (Garavan \& Morley, 1997). It is important for the academic community to foster relationships with students and the business community to develop and maintain open lines of communication to assess the 
preparation students receive and the skills, competencies and experiences necessary to new graduates to be successful (Graf, 1997).

According to Gabric and McFadden (2000), many of the desired skills can be achieved through curricula experiences. Kane's (1993) reported that employers and recruiters focus on people skills because they assume that graduates have the applicable technical and analytical skills. The goal is to improve the application oriented instruction and assessment in MBA programs (Buckley, Peach \& Weitzel, 1999; Hammond, Hartman \& Brown, 1996; McFadden, Jansen \& Towell, 1999). DiMartino and Castaneda (2007) found critical thinking and creative thinking can be fostered through internships and other independent projects. The applied skill sets developed through these internships and projects include empirical reasoning, quantitative reasoning, communication, social reasoning and personal qualities, all identified as needed skills by the Partnership for $21^{\text {st }}$ Century Skills (DiMartino \& Castaneda, 2007).

Competency-based education as the focus in higher education will help build the skills students need to be successful graduates (Neely and Tucker, 2012). Students need to use prior knowledge, recent learning, and relevant skills to solve realistic, complex problems while in a higher education setting to provide the competencies to be successful in a post-graduate position (DiMartino \& Castaneda, 2007). Instructional practices should include a greater emphasis on analysis, communication, meaningful problem solving and writing (DiMartino \& Castaneda, 2007). Development of curriculum project-based learning to develop empirical reasoning, quantitative reasoning, communication, and social reasoning along with self-confidence, self-motivation, resilience, and adaptability (DiMartino \& Castaneda, 2007). 


\section{Summary}

While billions are spent trying to develop competencies, the results for business students have been below expectations (Boyatzis, 2007). Successful new graduates and effective leaders need to use knowledge, skills, competencies, and experiences to make things happen (Boyatzis, 2007). Current MBA programs primarily improve the students' analytical abilities (Boyatzis \& Sokol, 1982; Porter \& Kibbin, 1988). Thus, leaving under-

developed, the skills and competencies identified by the Partnership for $21^{\text {st }}$ Century, the skills job entrants most need for success in the workplace are oral and written communication, time management, critical thinking, problem solving, personality accountability, and the ability to work effectively with others (DiMartino \& Castaneda, 2007). 


\section{SECTION FOUR}

\section{CONTRIBUTION TO PRACTICE}

\section{Plan for Dissemination of Practitioner Contribution}

Who: Leadership, faculty and staff, Trulaske College of Business, Crosby MBA Program, University of Mo-Columbia

When: 2018 spring semester How: Slide show presentation

\section{Presentation}

Document type will be a slide show presentation presented at the leadership, faculty, and staff meeting. The slide show will inform the audience of the perceptions of employers, current MBA students and recent MBA graduates of the skills, competencies, and experiences needed to be successful in new MBA graduate work positions. Upon request the full report will be made available.

\section{Rationale for this Contribution Type}

This contribution type is the preference of the Assistant Dean MBA Programs.

\section{Outline of Proposed Contents}

- Statement of Problem and Purpose of the Study

- Gaps in Literature

- Design of Study and Conceptual Framework

- Site Description and Setting

- Research Participants

- Research Questions

- Findings: Themes and Syllabus Analysis

- Suggestions for Further Research

- Conclusion

- References

\section{Slide Show with Notes}




\title{
Perceptions of MBA Preparation: \\ New Master of Business Administration Graduates, Their Employers, and Higher Education Faculty
}

\author{
Jan Whitlow \\ University of Missouri-Columbia
}

\section{Statement of the Problem}

- A college education provides a ticket to an affluent middle class life or better (Veddar, Denhart \& Robe, 2013).

- In 2014 , the median earnings of young adults with a master's degree or higher were $\$ 59,100,18$ percent higher than young adults with a bachelor's degree (Annual Earnings of Young Adults, 2016).

- MBA graduates are known for having specialized training in the functions of business, vocational maturity, a strong sense of career focus and values, are socialized in managerial and corporate value and possess a powerful ticket to success (Bruce, 2010; Dougherty, Dreher \& Whitely, 1993; Feldman, 2007; Veddar, Denhart \& Robe, 2013).

- Higher levels of management typically require an MBA 


\section{Statement of the Problem}

- According to Casner-Lotto and Barrington (2006), "The future workforce is here, and it is woefully ill-prepared for the demands of today's (and tomorrow's) workplace" (CasnerLotto \& Barrington, 2006, p. 9).

- According to the Graduate Management Aptitude Test Blog Hub, based upon a survey of 600 employers, managers want new graduate business hires to be communicators. People who can speak well, write well, listen to others, and present and sell ideas ("Employers Want Communication Skills in New Hires", 2014).

\section{Statement of the Problem}

- According to (Hobson et al., 2014), appeals have occurred for restructuring of MBA programs and business school curricula to better prepare students for workplace success.

- There is concern about whether students are developing the skills necessary for success in the tight competitive job market (Berdan, 2012). 


\section{Statement of the Problem}

DiMartino and Castaneda (2007), indicate that the skills new job entrants most need for success in the workplace include oral and written communication, time management, critical thinking, problem solving, personal accountability, and the ability to work effectively with others.

\section{Purpose of the Study}

The purpose of this study is to discover the possible gap in new knowledge between employers' perceptions of MBA graduates' skills and competencies, whether recent MBA graduates themselves believe they possess the skills and whether the curriculum provides the opportunity for students to develop the skills to be successful in their post-graduate position. 


\section{Gap in Literature}

- Little is known about whether MBA graduates possess the skills and competencies to be successful in their new graduate job and beyond.

- Research by (Brown, Cober, Kane, Levy, \& Shalhoop, 2006), found there is a critical nature to the first post-graduation job, as it launches a career and leads to other opportunities 


\section{Design of Study}

Qualitative case study

Extant literature

Syllabi analysis

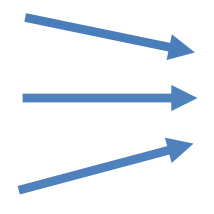

\section{Triangulation}

Surveys

\section{Conceptual Framework}

- Conceptual framework for this study is the Framework for $21^{\text {st }}$ Century Learning developed by the Partnership for $21^{\text {st }}$ Century Learning (P21), an organization that advocated for $21^{\text {st }}$ century readiness for every student (2011).

- The initiative of the Partnership for $21^{\text {st }}$ Century Learning is to provide tools and recourses to help educators in the United States by integrating the core content subjects along with critical thinking, problem solving, communication, collaboration, creativity, and innovation.

- All are necessary skills and competencies for gainful employment in their desired occupation (Epstein, 2010). 


\section{Site Description and Setting}

- Large Midwestern University

- The site is situated in a large Midwestern city (population 108,000), according to 2016 Suburban Stats, Inc.

- The population is predominantly White 79\%, African American $11 \%$, Asian 5\%, and Hispanic or Latino 3\% ("State and county,").

- The median household income is $\$ 72,913$ compared with the median income for the state $\$ 61,299$ ("State and county,").

- The large Midwestern university has a student enrollment of 35,441 , including 4,000 students in the College of Business undergraduates and $300 \mathrm{MBA}$ students.

- The student population is predominantly White $77 \%$, African American 7\%, Asian 2\%, and Hispanic or Latino 3\% ("Statistics and Demographics").

\section{Research Participants}

- Syllabi for the MBA core courses

- Current MBA students

- Recent (2016 and 2017) MBA graduates

- Employers of (2016 and 2017) MBA graduates

- MBA faculty for core courses

- The researcher will use non-probability, purposeful sampling to discover, understand and gain insight Merriam (2009, p. 77-79). 


\section{Research Questions}

-What are the manager's perceptions of the skills, competencies, and experiences recent MBA graduates do not yet possess?

- What are the MBA students' and recent graduates' perceptions of the skills, competencies, and experiences needed to be successful in their post-graduation job?

- What higher education teaching practices and/or curricula are needed to effectively prepare students for their post-graduate jobs? 


\section{Findings}

Themes

Critical Thinking

Communication

Teamwork/Leadership

Data analysis 


\section{Critical Thinking}

- Of the 16 core courses for the MBA program, only three included learning objectives to develop critical thinking skills.

- An employer of recent MBA graduates suggests:

More work with real business cases (problem solving).

Enhanced opportunities for "real world" experiences (guest speakers, corporate visits).

Ensure coursework links to today's business needs/environments.

Continue to support internships, value of experience, networking.

- Five of the 25 recent graduates and 13 of the $29 \mathrm{MBA}$ students indicated that critical thinking skills were important 


\section{Communication}

\section{- Feedback from faculty}

Critical thinking, creative thinking, broad perspective taking/ability to see issues from multiple points of view, communication skills (oral and written; using data to persuade others; ability to tell compelling stories to persuade others), tact and diplomacy, leadership, vision, willingness to take calculated risks and to own mistakes, learning (ability to learn a new position or issue area quickly, know how to evaluate the credibility of sources and data), project management skills, self management skills (emotional control, time management, goal setting, prioritization)

\section{- Feedback from employers}

- Communication, demonstrated collaborative skills, ability to drive results

- Efficient communication 


\section{Communication}

12 of the 29 MBA students and 19 of the 25 recent MBA graduates indicated communication was an important skill

Importance of Communication Skills

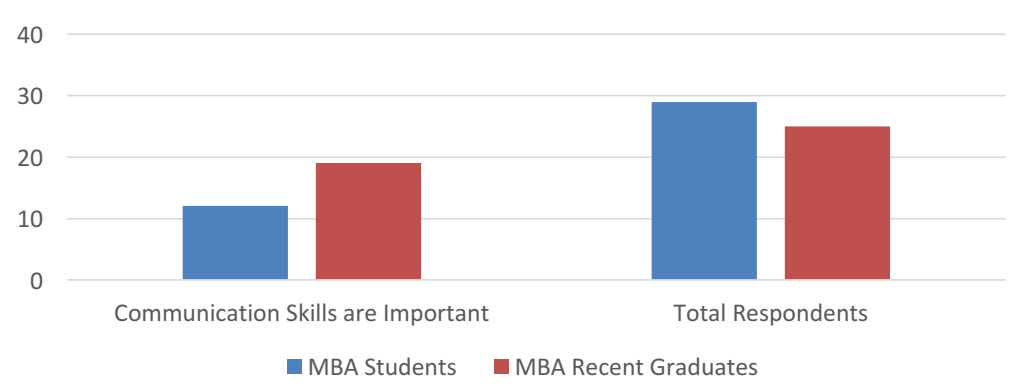




\section{Teamwork/Leadership}

\section{- Feedback from employers}

Highly collaborative, servant leader, open to learn and make mistakes, strong communicator, driven to understand people and acknowledge that uniqueness in people is what makes teams strong, adaptable, understanding of how businesses function, tools and techniques for building high performing teams, experience handling various types of conflict, negotiation for win-win

- 21 of the 29 MBA students and 7 of the 25 recent graduates indicated that teamwork and leadership are necessary skills. 


\section{Data Analysis}

- Feedback from employers regarding the skills needed to be successful in a post-graduate position:

Leadership

Analytical projects

Real world experience in a full time role (at least 3 years in a career before obtaining a degree)

- 7 of the 29 MBA students 11 of the 25 recent graduates and thought data analysis was a necessary skill to be successful 


\section{Responses from Recent MBA Graduates}

What should change about the MBA program to better prepare graduates?

- More case studies, individual critical thinking projects

- Balance traditional lectures with experiential learning opportunities

- Wider variety of classes, more case based courses, not just memorizing lists

Some sort of structured learning in communication is my number one suggestion. The communication course was nonsense during my semester, and the group presentations that persisted through most of the courses is useless in any job setting I've ever seen

(standing up in front of a screen with four others in a case competition-style presentation saying things like, "I'll now pass the clicker to sally to talk about our recommendations slide").

There are tons of opportunities in the Mizzou MBA program to learn great skills, but they're nearly useless without the ability to effectively share the fruit of those skills to coworkers, clients, and bosses. And that's the end of my rant. 




Again, I think that many lectures can be replaced will case studies. Many classes are sometimes more lecture oriented than discussions between students and professors. Lecturers are for undergrads. It's important for more discussion to foster new ideas and viewpoints between students.

I was a straight through student. In my 4 months of employment, I wish I would have done my MBA later in life. I have experience now to tie back to a great deal of my courses and bring a different perspective to the table. I see my MBA education now as an edge to my career, rather than another credential on my application. 


\section{Responses from MBA Students}

Skills needed to be successful in a post-graduation job: Critical/analytical thinking, verbal communication, ability to defend work and recommendations, ability to train or explain things to others

Suggesting students to participate in more case competitions, real consulting projects or research projects

Eliminate busy work from classes and do more case studies and real world examples 


\section{Responses from MBA Students}

Many of these classes need to be revamped. Teach us things we can and will use in the real world rather than make us do busywork and mock simulations that aren't actually teaching anything.

Certain classes are not taught effectively. I think traditional lecture-based courses should not be considered MBA level. Students need an environment where they are expected to contribute to conversations on a daily basis. This will help them be more comfortable in an office environment

More real life examples.. like expanding the consulting class. or working with industry professionals

\section{Responses from MBA Faculty}

Again, the jobs MBAs take are pretty varied. Generally, I would say working with clients on real world problems (consulting teams), case competitions, pitch competition are build multiple competencies. I also think they need to be put into unstructured, ambiguous situations in teams and be asked to "figure it out" without much guidance. I also think too many MBA students lack perseverance: They get anxious and blame outside forces (unclear assignment, bad teacher, not enough time) rather than regroup, step back, look at the big picture and figure out how to be successful in difficult situations. At least, corporate managers complain about those things: they say MBAs expect too much direction, and need too much coaching and praise for what they are being paid. 


\section{Responses from MBA Employers}

Positive and collaborative attitude.

Great verbal and written communication skills.

A desire to continuously learn.

Ability to understand business processes from end to end, and how their piece fits into that process.

Ability to be politically savvy.

Highly collaborative, servant leader, open to learn and make mistakes, strong communicator, driven to understand people and acknowledge that uniqueness

in people is what makes teams strong, adaptable, understanding of how businesses function, tools and techniques for building high performing teams, experience handling various types of conflict, negotiation for win-win

\section{Suggestions for Further Research}

- Increase the sample to include additional MBA programs recent graduates, employers, students and faculty and syllabi analysis.

- Compare the responses from employers of MBA graduates with and without work experience after completing their bachelor's degree, prior to starting the MBA program.

- Interview employers of recent MBA graduates to identify the most successful employees. Evaluate the MBA programs that produced these exemplary employees. 


\section{Conclusion}

This research further validates the extant research of

DiMartino and Castaneda (2007), which indicated that the skills new job entrants most need for success in the workplace include oral and written communication, time management, critical thinking, problem solving, personal accountability, and the ability to work effectively with others.

Further research to evaluate increase the sample size and include additional MBA programs along with identifying exemplary employees with MBA degrees and evaluating the programs that produced those graduates. 


\section{Therefore....}

The initiative moving forward is for faculty, MBA program administration and employers of MBA graduates to collaborate and determine the course content, assignments, and cases to develop, refine, and master the following skills and competencies.

$$
\begin{gathered}
\text { Oral and Written Communications Skills } \\
\text { Critical Thinking } \\
\text { Leadership/Teamwork } \\
\text { Data Analysis }
\end{gathered}
$$

\section{References}

Admissions. (n.d.). Retrieved October 23, 2016, from https://business.missouri.edu/programs-and-admissions/crosby$\underline{\mathrm{mba} / \text { academics/concentrations }}$

Annual Earnings of Young Adults. (2016, May 01). Retrieved June 21, 2016, from http://nces.ed.gov/programs/coe/indicator_cba.asp

Berdan, S. N. (2012, February 04). Top Skills MBA Grads Need for Success. Retrieved March 30, 2016.

Brown, D. J., Cober, R. T., Kane, K., Levy, P. E., \& Shalhoop, J. (2006). Proactive personality and the successful job search:a field investigation with college graduates. Journal of Applied Psychology, 91(3), 717-726. doi: 10.103700219010.91.3.717.

Bruce, G. D. (2010). Exploring the value of MBA degrees: Students' experiences in full-time, part-time and executive MBA programs. Journal of Education for Business, 85, 38-44. DOI: 10.1080/08832320903217648 


\section{References}

Casner-Lotto, J. \& Barrington, L. (2006). Are they really ready to work? Employers' perspectives on the basic knowledge and applied skills of new entrants to the $21^{\text {st }}$ century U.S. workforce, p.9: Conference Board, Corporate Voices for Working Families, Partnership for $21^{\text {st }}$ Century Sills, and Society for Human Resource Management. Columbia Missouri Household Income. (2014). Retrieved April 03, 2016, from http://www.deptofnumbers.com/income/missouri/columbia/ Creswell, J.W. (2009). Research design: Quantitative, qualitative, and mixed methods approaches (3rd ed.). Thousand Oaks, CA: Sage. Crosby MBA. (n.d.). Retrieved June 14, 2016.

Dede, C. (2010). Comparing frameworks for 21st century skills. In J. Bellanca \& R Brandt (Eds.), 21st century skills: Rethinking how students learn (pp. 51-76). Bloomington, IN: Solution Tree Press.

\section{References}

DiMartino, J., \& Castaneda, A. (2007, April 01). Assessing Applied, The Carnegie unit, awarding course credit for seat time, is working against efforts to teach and test 21st century workforce skills. Educational Leadership, 38-42.

Dougherty, T., Dreher, G., \& Whitely, W. (1993). The mba as careerist:an analysis of early career job change. Journal of Management, 19(3), 535-548.

Employers Want Communication Skills in New Hires. (2014, August 7). Retrieved March 30, 2016, from http://www.mba.com/us/the-gmat-blog-hub/the-official-gmatblog/2014/aug/employers-want-communication-skills-in-new-hires.aspx

Enrollment Data. (2016, May). Retrieved July 07, 2016, from nwmissouri.edu

Framework for 21st Century Learning. (2007, July 23). Retrieved June 14, 2016, from www.21stcenturyskills.org

Hobson, C. J., Strupeck, D., Griffin, A., Szostek, J., \& Rominger, A. S. (2014, July 01). Teaching MBA Students Teamwork and Team Leadership Skills: An Empirical Evaluation of a Classroom Educational Program. American Journal of Business Education, 7(3), 191-212 


\section{References}

McTighe, J., \& Seif, E. (2010). An implementation framework to support 21st century skills. In J. Bellanca \& R. Brandt (Eds.), 21st century skills: Rethinking how students learn (pp. xiii-xxix). Bloomington, IN: Solution Tree Press.

Merriam, S.B. (2009). Qualitative research: A guide to design and implementation. Hoboken, NJ: Jossey-Bass.

Merriam, S. B., \& Bierema, L. L. (2014). Adult learning: Linking theory and practice. San Francisco, CA: Jossey-Bass John Wiley \& Sons.

Partnership for 21st Century Skills. (2011, March). Framework for 21st century learning. Washington, DC: Retrieved from Partnership for 21st century skills website: http://www.p21.org/storage/documents/1._p21_framework_2-pager.pdf P21 Framework Definitions. (2015, May). Retrieved July 31, 2016, from http://www.p21.org/storage/documents/docs/P21 Framework Definitions New_Lo go_2015.pd

\section{References}

Pink, D. (2009). Drive: The surprising truth about what motivates us. New York, NY: Riverhead books.

Post-Graduation Data. (2015, May). Retrieved July 07, 2016, from nwmissouri.edu State and County Quick Facts. (2015, July 1). Retrieved July 7, 2016.

Veddar, R., Denhart, C., \& Robe, J. Center for College Affordability and Productivity, (2013). Why are recent college graduates underemployed? university enrollment and labor-market realities. 


\section{SECTION FIVE}

\section{CONTRIBUTION TO SCHOLARSHIP}

\section{Target Journal}

The target journal for publication is the Academy of Management Learning and Education. The Academy of Management Learning and Education is part of the Academy of Management organization.

\section{Rationale for this Target}

Published quarterly, the Academy of Management Learning and Education journal publishes articles on pressing issues in the fields of management education and learning. Articles presented include theory, models, research, critiques, dialogues and retrospectives. The audience includes scholars, educators, program directors and deans at academic institutions along with practitioners in training and corporate education.

All submissions receive a rigorous double-blind peer-review process. This includes one or more of the guest editors functioning as an action editor with final review from the Academy of Management Learning and Education journal editor.

Title page

\section{Outline of Proposed Contents}

Abstract (200 words or less)

Introduction of the Problem

Review of the literature

Theoretical framework

Research questions

Methods

Results

Discussion

References

Who: Manuscript Central

\section{Plan for Submission}

Jan Whitlow upon defense of this dissertation

When: Spring 2017, publication dates March, June, September and December

How: http://mc.manuscriptcentral.com/amle

PERCEPTIONS OF MBA PREPARATION: NEW MASTER OF BUSINESS ADMINISTRATION GRADUATES, THEIR EMPLOYERS, AND HIGHER EDUCATION FACULTY 


\begin{abstract}
:
This qualitative study compares perceptions of Master of Business Administration (MBA) students and recent MBA graduates with those of employers of recent MBA graduates and MBA faculty regarding the skills, competencies, and experiences needed to be successful in their new graduate jobs. The researcher gathered stakeholder perspectives on the skills, competencies and experiences needed to create a successful new MBA graduates through surveys and archival data. Stakeholders included recent MBA graduates, MBA students, MBA faculty, and employers of recent MBA graduates. Analysis included MBA students and graduates, MBA employers, MBA faculty, and higher education practices. Results suggest that critical thinking, communication, teamwork, leadership along with data analysis are the necessary skills, competencies, and experiences needed to be successful in a post MBA graduate position. This research further validates the extant research of DiMartino and Castaneda (2007), which indicated that the skills new job entrants most need for success in the workplace include oral and written communication, time management, critical thinking, problem solving, personal accountability, and the ability to work effectively with others. Implications of this research are to advance the academic preparation of MBA students; to improve their oral and written communications skills, critical thinking, teamwork, leadership, and data analysis.

Keywords: MBA education, instructional-learning framework, competencies, recent MBA graduates, skills, experiences, leadership, teamwork, communication, critical thinking, and data analysis.
\end{abstract}




\section{Introduction of the Problem}

For the 300 students served by the traditional MBA program of this large Midwestern University, there is concern about whether they are developing the skills necessary for success in the tight competitive job market (Berdan, 2012). According to Casner-Lotto and Barrington (2006), "The future workforce is here, and it is woefully illprepared for the demands of today's (and tomorrow's) workplace" (Casner-Lotto \& Barrington, 2006, p. 9). According to the Graduate Management Aptitude Test Blog Hub, based upon a survey of 600 employers, managers want new graduate business hires to be communicators. People who can speak well, write well, listen to others, and present and sell ideas ("Employers Want Communication Skills in New Hires", 2014). Are these communication skills taught and developed as part of the 21 month MBA educational process at this large Midwestern University? Is higher education staying abreast with the most desirable content and fieldwork to prepare new graduates for the expectations of their future employers?

\section{Review of the literature}

Higher education is responsible for preparing students for the job market (Epstein, 2010). Students need to be prepared for gainful employment in the field or the occupation studied, occupations requiring an education to secure, that pay enough to afford the opportunity to repay student loans (Epstein, 2010). A college degree is a signal of drive and talent and indicates a person is smarter, more intelligent, reliable and disciplined and provides a ticket to an affluent middle-class life or better (Veddar, Denhart \& Robe, 2013).

As part of career advancement and the pursuit of a meaningful career that offers long-term advancement and personal satisfaction, individuals chose to enroll in a Master of 
Business Administration MBA programs (Muja \& Appelbaum, 2012). Casner-Lotto and Barrington (2006), suggest MBA graduates are ill-prepared for the demands of the current and future work environment. New job entrants need oral and written communication skills, time management, critical thinking, problem solving, personal accountability, and the ability to work effectively with others (DiMartino \& Castaneda, 2007).

The initiative of the Partnership for $21^{\text {st }}$ Century Learning is to provide the tools and resources to help educators in the United States by integrating the core content subjects along with critical thinking, problem solving, communication, collaboration, creativity, and innovation. Whether these skills and competencies are present in MBA graduates will be researched through the lenses of $21^{\text {st }}$ Century Learning student outcomes. While these skills are recognized by the Partnership for $21^{\text {st }}$ Century Learning, are they recognized by employers, MBA students and recent MBA graduates? Is the development of these skills incorporated into the MBA curriculum and assessment to help prepare MBA graduates for the workforce?

The Partnership for $21^{\text {st }}$ Century Learning (P21 Framework, 2015) developed a unified vision and framework that describes the skills, knowledge, and expertise students need to succeed in work and life. Students build from the base of academic subject knowledge and think critically and communicate effectively to be successful in work and life (P21 Framework, 2015). Themes for student outcomes include mastery of the key subjects and $21^{\text {st }}$ century themes global awareness, financial, economic, business and entrepreneurial literacy, civic literacy, health literacy and environmental literacy (P21 Framework, 2015). Student outcomes also include learning and innovation skills, creativity and innovation, critical thinking and problem solving, along with communication and 
collaboration (P21 Framework, 2015). Finally, information, media, and technology skills and life and career skills complete the unified vision and framework for $21^{\text {st }}$ century learning.

Business managers face intense competition and need employees who are prepared to be competent business leaders of the $21^{\text {st }}$ Century (Kedia \& Harveston, 1998). Students need a holistic approach to teaching and learning so they view business problems in their entirety from analysis, using the mastery of key academic subject area content to implementation (Kedia \& Harveston, 1998). According to Lee and Hung, $21^{\text {st }}$ Century learning is about the interactions between theory and practice. By combining individuals and business, formal and informal learning, the tacit knowledge is formed and becomes useful in practice. Learners are equipped with content knowledge of traditional disciplines such as finance, technology, management, statistics and need to be aligned with business problems and applications (Lee \& Hung, 2012). In their study of $21^{\text {st }}$ century workforce skills, DiMartino and Castaneda (2007) find that in the national obsession with core content expertise there is a distraction from the skills students need for success, critical thinking, collaboration, and communication skills.

Learning and innovation skills are what prepare students for the work environment in today's world (P21 Framework, 2015). These skills including emotional and social intelligence can be developed in graduate management programs (Boyatzis, 2008). MBA students benefit from problem solving cases that require teamwork along with feedback from professors, to improve their leadership and teamwork skills (Hobson, Strupeck, Griffin, Szostek \& Rominger, 2014). Employers of MBA graduates are looking for 
graduates with business experience who can solve problems and demonstrate they can use critical thinking, collaboration and communication skills (Neeley \& Tucker, 2012).

In order to navigate complex life and work environments, today's students need to develop life and career skills including thinking skills, content knowledge, and social and emotional competencies (P21 Framework, 2015). Students enhance skills such as team bonding, developing refinement strategies while the work is in progress, filtering critical information, and making the best of a situation through the use of multiple life and career skills (Shaari \& Lee, 2012). Real life requires the ability to integrate and filter knowledge, experience, skills, attitudes, along with emotional, social and cognitive intelligence and the ability to apply them to new and challenging problems and situations (Gulikers, Bastiaens \& Kirschner, 2004; Boyatzis, 2008).

Today's work place is a technology and media-driven environment and requires access to a wealth of information with rapid changes in technology and the need to collaborate to keep abreast of changes (P21 Framework, 2015). Employers value technical skills and knowledge of database management, resourcefulness, data search skills and integration of complex information and data (Gabric \& McFadden, 2000). University students entering the workforce need to have a comprehensive knowledge of technology and an understanding of how technology supports problem solving by going beyond basic office suite skills, e-mailing, text messaging, Facebook and surfing the Internet (Kirschner \& Van Merrienboer, 2013; Darling-Hammod \& Snyder, 1999).

\section{$21^{\text {st }}$ Century MBA Employers}

The Partnership for 21st Century Learning (P21) describes the skills, knowledge and expertise students should exhibit to be successful in work and life (2011). These skills 
including critical thinking, communication, and creativity are also recognized by employers of recent MBA graduates as marketable skills necessary for success (Berdan, 2012). Little research focuses on the link between the business community and students (Gabric \& McFadden, 2000). Clear differences exist between the skills needed by the business community and the skills acquired by the students (Gabric \& McFadden, 2000). According to Boyatzis and Sokol (1982) and Porter and McKibbin (1988), MBA programs predominantly improve students' analytical skills. The reasons recent graduates remain unemployed, were poor communication and problem-solving skills, lack of industrial training exposure, bad attitudes and lack of self-confidence (Wong, 2010). The future workforce is woefully ill-prepared for the demands of the workforce (Casner-Lotto \& Barrington, 2006)

The skills job entrants most need for success in the workplace include oral and written communication, time management, critical thinking, problem solving, personal accountability, and the ability to work effectively with others, however, all skills the graduates evaluated in a recent study conducted by the Partnership for $21^{\text {st }}$ Century Skills and three other organizations were lacking (DiMartino \& Castaneda, 2007). The study surveyed 400 employers across the United States regarding the workforce readiness of high school and college graduates. This research found that the skills new job entrants most need for success in the workplace, are the skills the graduates are least prepared to demonstrate (DiMartino \& Castaneda, 2007). Emphasis is needed on skills, such as self-confidence, selfmotivation, resilience, and adaptability (DiMartino \& Castaneda, 2007).

Gabric and McFadden (2000) found a significant difference between employers and students' perceptions of the importance of the critical skills necessary for successful 
employment. Three categories emerged qualitative, quantitative, and personal attributes. Qualitative or general business skills included working in teams, problem-solving, handling ambiguous situations, and effective communications (Gabric \& McFadden, 2000). Quantitative skills or technical skills included analytical skills, programming, database management (Gabric \& McFadden, 2000). Personal attributes include being conscientious, motivated, and ethical (Gabric \& McFadden, 2000).

According to the Graduate Management Aptitude Test Blog Hub, based upon a survey of 600 employers, managers want new graduate business hires to be communicators. People who can speak well, write well, listen to others, and present and sell ideas ("Employers Want Communication Skills in New Hires", 2014). Managers assume MBA candidates have core business knowledge, strong analytical skills, quantitative and technical skills. However, the top four skills managers require in new business graduates are communication-related skills, including oral and listening skills, written communication, presentation skills, and teamwork ("Employers Want Communication Skills in New Hires", 2014). Managers expect MBA graduates to be the future, strong, effective, leaders of their organizations and with that expectation, desire their new MBA graduates to possess not only the technical skills, along with strong communication and interpersonal skills ("Employers Want Communication Skills in New Hires", 2014).

Managers assume recent graduates are knowledgeable and capable of performing their work independently and are surprised when the recent graduates need more performance feedback and a more structured work environment (Jusoh, Simun and Chong, 2011). The academic methods of performance feedback leave the students unprepared for the expectations of the work environment (Jusoh, Simun and Chong, 2011). Recent 
graduates are also seen as too theoretical, naïve, and idealistic, along with immature and inexperienced (Shein, 1964; Holton, 1992).

\section{MBA Graduates}

Little research has examined the expectations of new business graduates, their knowledge of post-graduate job expectations and demands, and the preparation to meet those demands and expectations (Garavan \& Morley, 1997). MBA students believe having an MBA is a means of developing a multidisciplinary and broad functional knowledge that is relevant in many industries. It is a "ticket" to increased salary and senior management (Muja \& Appelbaum, 2012). College graduates enter the workforce with expectations, mainly based on what they have been taught, that they will obtain satisfied, secure, and well-paying employment (Shelley, 1994). MBA students expect to receive achievement, recognition, responsibility, and advancement with their degree (Muja \& Appelbaum, 2012). Cognitive skills and motivation will drive their post-graduation job success, are the beliefs of MBA students (Holton \& Russell, 1997).

Students enter MBA programs intending to develop their leadership skills, increase their earnings, and experience the real-world by interacting with executives and professors. MBA students achieve this knowledge and experience through classes, cases and community service. The MBA program at this large Midwestern University is nationally recognized and AACSB accredited (MBA Strategic Plan, 2016). The two-year, full time, 57 (including 22 credit hours of electives) credit hour program includes 120 students, 44\% are female, 35\% international, and 7\% minority (Admission, 2016). Most students, $80 \%$ enter with a Graduate Management Admissions GMAT score of 600-670 and an undergraduate GPA of 3.5 or higher (Admission, 2016.) While previous courses in accounting, finance and 
statistics are helpful, students are admitted from any undergraduate program (Admission, 2016).

The academic work focuses on building a customized curriculum and professional development program to prepare students for a successful career. The first year of the MBA program includes strong foundational courses in Data Analysis, Managerial Marketing, Microeconomics for Business, Finance, Organizational Behavior, Management Information Systems, Operations Strategy, and Statistics. The second-year curriculum includes, Financial Statement Analysis, Ethics and Leadership, Strategic Global Competitiveness and elective courses in Finance, Management or Marketing.

\section{Higher Education Teaching Practices and Curricula}

In between employers and college graduates are universities whose role is to prepare graduates for the competitive job market (Sewell \& Pool, 2010). Universities are under pressure from parents, students, and the business community to prepare students to be productive employees, good citizens, and dedicated, responsible, knowledgeable professionals (Heitkemper, 1998). Holton (1992) emphasized after interviewing hundreds of new employees, managers and executives that although universities had excelled at teaching technical skills, too little attention is placed on teaching graduates how to go to work. Universities play a major role in preparing the expectations of new graduates (Garavan \& Morley, 1997).

Universities should regularly revise and develop academic programs to better prepare students for the jobs of tomorrow (Gabric \& McFadden, 2000). Research suggests redirecting instruction to a more balanced approach to focus on core content knowledge and applied skills (knowledge, work habits, and character traits) with feedback provided 
through authentic assessment (Darling-Hammond, Rustique-Forrester, \& Pecheone, 2005; Herman, 1997; Wiggins, 1990). Authentic assessments require students to use prior knowledge, recent learning, and relevant learning to solve complex problems (DiMartino \& Castaneda, 2007).

Improved communication between employers and MBA academic leadership will aid in the development of human capital and improve workforce efficiency (Muja \& Appelbaum, 2012). Understanding the trends and receiving feedback from the business community will allow business schools to improve their curriculum and assessment and better prepare students for the workplace demands and objectives (Garavan \& Morley, 1997). It is important for the academic community to foster relationships with students and the business community to develop and maintain open lines of communication to assess the preparation students receive and the skills, competencies and experiences necessary to new graduates to be successful (Graf, 1997).

According to Gabric and McFadden (2000), many of the desired skills can be achieved through curricula experiences. Kane's (1993) reported that employers and recruiters focus on people skills because they assume that graduates have the applicable technical and analytical skills. The goal is to improve the application oriented instruction and assessment in MBA programs (Buckley, Peach \& Weitzel, 1999; Hammond, Hartman \& Brown, 1996; McFadden, Jansen \& Towell, 1999). DiMartino and Castaneda (2007) found critical thinking and creative thinking can be fostered through internships and other independent projects. The applied skill sets developed through these internships and projects include empirical reasoning, quantitative reasoning, communication, social reasoning and 
personal qualities, all identified as needed skills by the Partnership for $21^{\text {st }}$ Century Skills (DiMartino \& Castaneda, 2007).

Competency-based education as the focus in higher education will help build the skills students need to be successful graduates (Neely and Tucker, 2012). Students need to use prior knowledge, recent learning, and relevant skills to solve realistic, complex problems while in a higher education setting to provide the competencies to be successful in a post-graduate position (DiMartino \& Castaneda, 2007). Instructional practices should include a greater emphasis on analysis, communication, meaningful problem solving and writing (DiMartino \& Castaneda, 2007). Development of curriculum project-based learning to develop empirical reasoning, quantitative reasoning, communication, and social reasoning along with self-confidence, self-motivation, resilience, and adaptability (DiMartino \& Castaneda, 2007).

\section{Summary}

While billions are spent trying to develop competencies, the results for business students have been below expectations (Boyatzis, 2007). Successful new graduates and effective leaders need to use knowledge, skills, competencies, and experiences to make things happen (Boyatzis, 2007). MBA programs primarily improve the students' analytical abilities (Boyatzis \& Sokol, 1982; Porter \& Kibbin, 1988). Thus, leaving under-developed, the skills and competencies identified by the Partnership for $21^{\text {st }}$ Century, the skills job entrants most need for success in the workplace oral and written communication, time management, critical thinking, problem solving, personality accountability, and the ability to work effectively with others (DiMartino \& Castaneda, 2007). 


\section{Theoretical framework}

\section{Conceptual Framework}

The conceptual framework for this study is the Framework for $21^{\text {st }}$ Century Learning developed by the Partnership for $21^{\text {st }}$ Century Learning (P21), an organization that advocated for $21^{\text {st }}$ century readiness for every student (2011). The initiative of the Partnership for $21^{\text {st }}$ Century Learning is to provide tools and recourses to help educators in the United States by integrating the core content subjects along with critical thinking, problem solving, communication, collaboration, creativity, and innovation. All are necessary skills and competencies for gainful employment in their desired occupation (Epstein, 2010). While the core content subjects including English, reading or language arts, world languages, arts, mathematics, economics, science, geography, history, government and civics, subjects commonly taught in the kindergarten thru $12^{\text {th }}$ grade education, these content areas and skills also apply to higher education development and learning in order to prepare students for the workforce.

According to Boyatzis (1982) one of the objectives of higher education is to prepare students to be outstanding professional managers and leaders. Additionally, Boyatzis (2007) discusses the emotional, social and cognitive intelligence competencies that predict effectiveness as a manager and leader. These competencies along with skills in communication, critical thinking, collaboration, resilience, innovation and creativity (Berden, 2011) all are needed to solve real-life problems (Gulikers, et al., 2004). The United States' national focus on proficiency in core content is disrupting the teaching of skills graduates need for success (Dimartino \& Castaneda, 2006). 
Figure 2 The Partnership for 21st Century Skills Framework for 21st Century Learning

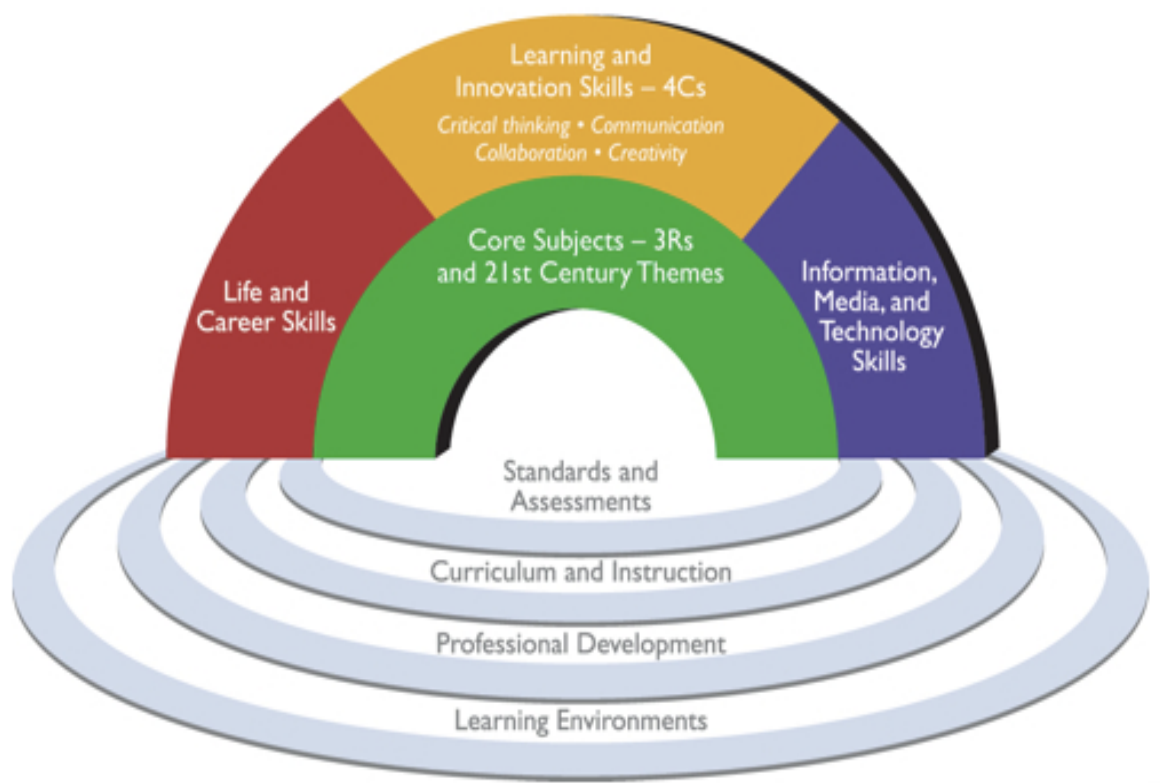

Figure 2. The four colored arches are the intended student outcomes of 21 st century learning. The four pools are the support systems needed for the outcomes to occur.

The first of the four themes defined by the Partnership for $21^{\text {st }}$ Century Skills are the core subject and $21^{\text {st }}$ century themes. The Partnership for $21^{\text {st }}$ Century Skills (2007) defines the core subjects as English, reading or language arts, arts, mathematics, economics, science, geography, history, and government and civics. Along with these subjects, the Partnership for $21^{\text {st }}$ Century Learning (2007) promotes the focus on moving beyond the basic competencies to an understanding of a higher level and weaving the $21^{\text {st }}$ century interdisciplinary themes into the curriculum. The themes include global awareness, financial, economic, business and entrepreneurial literacy, civic literacy, health literacy, and environmental literacy. According to (Hobson et al., 2014), appeals have occurred for restructuring of MBA programs and business school curricula to better prepare students for workplace success. 
The second of the themes defined by the Partnership for $21^{\text {st }}$ Century Learning (2007) is learning and innovation skills. These skills are what separate students who are prepared for the complexity of the demands of the work environment and those who unprepared (2007). These skills include creativity and innovation, critical thinking and problem solving, and communication and collaboration skills. DiMartino and Castaneda (2007), indicate that the skills new job entrants most need for success in the workplace include oral and written communication, time management, critical thinking, problem solving, personal accountability, and the ability to work effectively with others.

The third theme identified by the Partnership for $21^{\text {st }}$ Century Learning (2007) is life and career skills. These include flexibility and adaptability, initiative and self-direction, social and cross-cultural skills, productivity and accountability, and leadership and responsibility. Business schools in the $21^{\text {st }}$ Century view learning as a process that involves both responsibility and accountability, with learning as a complex, interactive and dynamic process (Kedia \& Harveston, 1998).

The final of the four themes information, media and technology skills. To be successful, employees must be able to exhibit a range of functional and critical thinking skills, including information literacy, media literacy, and information, communications and technology literacy. Students and employees live in a technology and media-driven environment. Kirschner and van Merrienboer (2013), found that university students do not really have a deep knowledge of technology and what knowledge they have is limited to basic office suite skills, e-mail, text messaging, Facebook, and surfing the Internet. 


\section{Research questions}

The overarching research question guiding this study is: What are the managers' perceptions of the skills, competencies, and experiences recent MBA graduates need?

Other questions guiding this study are:

1. What are the manager's perceptions of the skills, competencies, and experiences recent MBA graduates do not yet possess?

2. What are the MBA students' and recent graduates' perceptions of the skills, competencies, and experiences needed to be successful in their post-graduation job?

3. What higher education teaching practices and/or curricula are needed to effectively prepare students for their post-graduate jobs?

\section{Methods}

This case study, per Creswell (2009), is a strategy of inquiry bounded by time and activity where the researcher explores a program in depth. This study is created for educators to learn about the perceptions of employers of the skills and competencies MBA graduates should possess to be successful in their new graduate positions. Educators need to understand the skills and competencies that the new graduates are lacking and thus provide the opportunity and environment for MBA students to further develop those skills during their MBA education. With the main purpose of adding to the field of education and deepening the understanding of the skills and competencies to prepare MBA graduates for gainful employment, the researcher will be doing basic research. According to Merriam (2009), basic, interpretive study is common in applied fields such as education and business. 
Basic research could ultimately inform practice, however, its primary purpose is to know more about a phenomenon (Merriam, 2009).

The basic research used will be a case study of a bounded system (Merriam, 2009). The study is searching for meaning and understanding of the competencies MBA students acquire during their MBA education and the perceptions of their new graduate managers and their ability to apply those skills and competencies. The researcher is the primary collector of real-life data and analysis (Merriam, 2009). Such a project lends itself to a qualitative case study.

\section{Results}

\section{Critical Thinking Skills}

The MBA program includes 16 core courses while three courses included learning objectives to develop critical thinking skills. An employer of a recent MBA graduate suggested the students need more work with real business cases (problem solving), enhanced opportunities for "real world" experiences (guest speakers, corporate visits), ensure coursework links to today's business needs/environments, continue to support internships, value of experience, and networking.

\section{Communication Skills}

Communication skills, oral and written were a key concern of faculty and employers. Employers stated demonstrated collaboration skills, the ability to drive results and efficient communication. Twelve of the 29 MBA students and 19 of the 25 recent MBA graduates indicated communication was an important skill. One faculty member suggested that critical thinking, creative thinking, broad perspective taking/ability to see issues from multiple points of view, communication skills (oral and written; using data to persuade 
others; ability to tell compelling stories to persuade others), tact and diplomacy, leadership, vision, willingness to take calculated risks and to own mistakes, learning (ability to learn a new position or issue area quickly, know how to evaluate the credibility of sources and data), project management skills, self-management skills (emotional control, time management, goal setting, prioritization).

\section{Teamwork/leadership}

Seventy five percent of the MBA student survey respondents and twenty-eight percent of the MBA recent graduates indicated that teamwork and leadership skills were necessary to be successful in their recent graduate positions. Feedback from employers included that recent graduates should be highly collaborative, servant leaders, open to learn and make mistakes, strong communicators, driven to understand people and acknowledge that uniqueness in people is what makes teams strong, and adaptable. Graduates with the tools and techniques for building high performing teams, experience handling various types of conflict, and negotiation for win-win.

\section{Data Analysis}

Employers of recent MBA graduates want their employees to have experience with analytical projects. While forty-four percent to the recent MBA graduates and twenty-four of the MBA students thought data analysis was a necessary skill. Of the 18 core courses, three include learning objectives for data analysis. A sample of the learning objectives includes representing/visualizing data, associating and developing graphs with data, analyze data distributions and make probabilistic statements, interpret data and communicate understanding, and use data to make informed decisions. 


\section{Discussion}

Each of the four respondent/sample groups were asked how the MBA program could be improved to better prepare students for their post-graduate position and suggestions the faculty to help improve the skills, competencies, and experiences of the MBA graduates. While all four sample groups MBA students, recent graduates, faculty and employers agreed that students need more experiential learning. All groups expressed the need for unstructured, ambiguous situations in teams to figure out solutions without much guidance. More business cases, real world problem solving, and always with the opportunity to exhibit professionalism. Real consulting projects, hands-on experience and interaction with business people, business cases that help develop a higher level of thinking and creativity are suggestions from the four sample groups. 


\section{References}

Admissions. (n.d.). Retrieved October 23, 2016, from

https://business.missouri.edu/programs-and-admissions/crosby-

$\underline{\mathrm{mba} / \text { academics/concentrations }}$

Advancing quality management education worldwide. (2015, July). Retrieved from $\underline{\text { www.aacsb.edu }}$

Ajzen, I. (1991). The theory of planned behavior. Organizational Behavior and Human Decision Process, 50, 179-211.

Alsop, R. (2008). The trophy kids grow up: How the millennial generation is shaking up the workplace. San Francisco: Jossey- Bass.

Ancona, D., Malone, T., Orlikoswki, W., \& Senge, P. (2011). Leading Change. In HBR's 10 must reads on leadership (pp. 179-196). Boston, MA: Harvard Business Review Press. (Reprint R0702E, Originally published February 2007)

Annual Earnings of Young Adults. (2016, May 01). Retrieved June 21, 2016, from http://nces.ed.gov/programs/coe/indicator_cba.asp

Brinkerhoff, C. (2016, April 8). MBA Program Strategic Plan. Lecture presented at MBA Strategic Plan in College of Business, Columbia.

Brinkerhoff, C. (2016, July 27). Organizational and leadership analysis [E-mail to the author].

Bandura, A. (1986). Social foundations of thought and action: A social cognitive theory, Englewood Cliffs, NJ: Prentice Hall.

Berdan, S. N. (2012, February 04). Top Skills MBA Grads Need for Success. Retrieved March 30, 2016.

Blau, G. (1994). Testing a two-dimension measure of job search behavior. Organizational Behavior and Human Decision Process, 59, 288-312.

Bolman, L. G. \& Deal, T. E. (2008). Reframing organizations: Artistry, choice, and leadership (4th ed.). San Francisco, CA: Jossey-Bass.

Boyatzis, R.E., (2007). Competencies in the $21^{\text {st }}$ century. Journal of Management Development, 27(1), 5-12.

Boyatzis, R.E., (2008). A 20-year view of trying to develop emotional, social and cognitive intelligence competencies in graduate management education. Journal of Management Development, 27(1), 92-108. 
Boyatzis, R.E., \& Sokol, M. (1982). A pilot project to access the feasibility of assessing skills and person characteristics of students in collegiate business programs, report to the AACSB, St. Louis, MO.

Brown, D. J., Cober, R. T., Kane, K., Levy, P. E., \& Shalhoop, J. (2006). Proactive personality and the successful job search:a field investigation with college graduates. Journal of Applied Psychology, 91(3), 717-726. doi: 10.10370021-9010.91.3.717.

Bruce, G. D. (2010). Exploring the value of MBA degrees: Students' experiences in fulltime, part-time and executive MBA programs. Journal of Education for Business, 85, 38-44. DOI: 10.1080/08832320903217648

Buckley, M. R., Peach, E. B., Weitzel, W. (1989). Are collegiate business programs adequately preparing students for the business world? Journal of Education for Business, 45(3), 101-105.

Casner-Lotto, J. \& Barrington, L. (2006). Are they really ready to work? Employers' perspectives on the basic knowledge and applied skills of new entrants to the $21^{\text {st }}$ century U.S. workforce, p.9: Conference Board, Corporate Voices for Working Families, Partnership for $21^{\text {st }}$ Century Sills, and Society for Human Resource Management.

Columbia Missouri Household Income. (2014). Retrieved April 03, 2016, from http://www.deptofnumbers.com/income/missouri/columbia/

Competencies. (n.d.). Dictionary.com Unabridged. Retrieved January 3, 2017 from Dictionary.com website http://www.dictionary.com/browse/credentials

Coomes, M.D., DeBard, R. (Eds.) (2004). Serving the Millennial Generation. New Directions in Student Services. San Franciso, CA: Jossey Bass.

Cote, S., Saks, A. \& Zikic, J. (2006). Trait affect and job search outcomes. Journal of Vocational Behavior, 68, 233-252. doi:10.1016/j.jvb.2005.08.001.

Credentials. (n.d.). Dictionary.com Unabridged. Retrieved January 3, 2017 from Dictionary.com website http://www.dictionary.com/browse/credentials

Curriculum. (n.d.). Retrieved October 23, 2016, from https://business.missouri.edu/programs-and-admissions/crosby$\underline{\mathrm{mba} / \text { academics/concentrations }}$

Creswell, J.W. (2009). Research design: Quantitative, qualitative, and mixed methods approaches (3rd ed.). Thousand Oaks, CA: Sage.

Crosby MBA. (n.d.). Retrieved June 14, 2016. 
da Motta Veiga, S. P., \& Turban, D. B. (2014). Are affect and perceived stress detrimental or beneficial to job seekers? the role of learning goal orientation in job search selfregulation. Organizational Behavior and Human Decision Process, 125, 193-203. doi: 10.1016/j.obhdp.2014.09.007

Darling-Hammond, L., Rustique-Forrester, E., \& Pecheone, R. (2005). Multiple measures approaches to high school graduation. Stanford, CA:School Redesign Network at Stanford University.

Darling-Hammond, L., Snyder, J.. (2000). Authentic assessment of teaching in context. Teaching and Teacher Education, 12, 523-545.

Dede, C. (2010). Comparing frameworks for 21 st century skills. In J. Bellanca \& R. Brandt (Eds.), 21st century skills: Rethinking how students learn (pp. 51-76). Bloomington, IN: Solution Tree Press.

DiMartino, J., \& Castaneda, A. (2007, April 01). Assessing Applied, The Carnegie unit, awarding course credit for seat time, is working against efforts to teach and test $21 \mathrm{st}$ century workforce skills. Educational Leadership, 38-42.

Ding, H., \& Ding, X. (2013). 360-degree rhetorical analysis of job hunting: A four-part, multimodal project. Business Communications Quarterly, 76(2), 239-248. doi: $10.1177 / 1080569912475207$

Dougherty, T., Dreher, G., \& Whitely, W. (1993). The mba as careerist:an analysis of early career job change. Journal of Management, 19(3), 535-548.

Drake, P., \& Heath, L. (2011). Practitioner research at doctoral level developing coherent research methodologies. (First ed., pp. 46-58). London, New York: Routledge.

Drucker, P. F. (2011). What Makes an Effective Executive. Boston, Massachusetts: Harvard Business Review Press, 23-36.

Edmondson, A. C. (2012). Teaming: How organizations learn, innovate, and compete in the knowledge economy. San Francisco, CA: Jossey-Bass. (Selected readings)

Elam, C., Stratton, T., \& Gibson, D. (2007). Welcoming a new generation to college: The millennial students. Journal of College Admissions, Spring, 20-25. Retrieved from www.nacacnet.org

Employers Want Communication Skills in New Hires. (2014, August 7). Retrieved March 30, 2016, from http://www.mba.com/us/the-gmat-blog-hub/the-official-gmatblog/2014/aug/employers-want-communication-skills-in-new-hires.aspx 
Ennis, R. H. (2002, June 20). A super-streamlined conception of critical thinking. Retrieved July 07, 2016, from www.criticalthinking.com

Enrollment Data. (2016, May). Retrieved July 07, 2016, from nwmissouri.edu

Epstein, J. (2010). "Going ahead with gainful employment”, Retrieved April 2, 2016, from http://www.insidehighered.com/news/2010/04/21/gainful

Epstein, M., \& Howes, P. (2008). Recruiting, retaining and managing the millennial generation. Selected readings 2008-Management of a practice [CD ROM]. New York: American Institute of Certified Public Accountants.

Feldman, D. (2007). The food's no good and they don't give us enough: Reflections on Mintzberg's critique of MBAeducation. Journal of Education for Business, 82, 217-220.

Feldman, D.C. (1976). A practical programme for employee socialization. Organizational Dynamics, 5, 65-80.

Fink, A. (2013). How to conduct surveys: A step by step guide. Thousand Oaks, CA: Sage Publications, Inc.

Forgas, J. P. (1995). Mood and judgement: The affect infusion model (AIM). Psychological Bulletin, 117, 39-66.

Framework for 21st Century Learning. (2007, July 23). Retrieved June 14, 2016, from www.21stcenturyskills.org

Gabric, D., \& McFadden, K. L. (2000). Student and Employer Perceptions of Desirable Entry-Level Operations Management Skills. Mid-American Journal of Business, 16(1), 51-59.

Garavan, T. N., Morley, M., (1997). The socialization of high-potential graduates into the organization initial expectations, experiences and outcomes, Journal of Managerial Psychology, 12(2), 118-137. Available from ProQuest. (215867067).

Gault, J., Redington, J., \& Schlager, T. (2015). Undergraduate business internships and career success: Are they related? Unpublished manuscript, Available from ProQuest. (204412303).

Goffee, R., \& Jones, G. (2011). Why should anyone be led by you? In HBR's 10 must reads on leadership (pp. 79-95). Boston, MA: Harvard Business Review Press. (Reprint R00506, Originally published September 2000)

Goleman, D. (2011). What makes a leader? In HBR's 10 must reads on leadership (pp. 1- 
21). Boston, MA: Harvard Business Review Press. (Reprint R0401H, Originally published June 1996)

Gulikers, J.T., Bastiaens, T.J. and Kirschner, P.A. (2004), A five-dimensional framework for authentic assessment, Educational Technology Research and Development, Vol. 52 No. 3, pp. 67-85.

Graduate Management Admission Council. (2003a). Global MBA graduate

Graf, D. (1997). Critical success factors for community-based education. Mid-America Journal of Business, 12(2), 51-59.

Hammond, D.H., Hartman, S.J., Brown, R.A. (1996). The match between undergraduate academic instruction and actual field practices in production/operations management. Journal of Education for Business, 71(5), 263-266.

Harris, T.L., \& Hodges, R.E. (1995). The Literacy Dictionary The Vocabulary of Reading and Writing. Newark, DE: International Reading Association.

Heifetz, R. A., \& Laurie, D. L. (2011). The Work of Leadership. Harvard Business Review On Leadership, 57-79.

Heitkemper, M.R. (1998). Work-study experience of college graduates as it relates to the transition to work and job satisfaction. Unpublished academic dissertation, Gonzaga University, Spokane, WA.

Herman, J. (1997). Assessing new assessments: Do they measure up? Theory into Practice, 36(4), 196-204.

Hershatter, A., \& Epstein, M. (2010). Millennials and the world of work:an organizational and management perspective. Journal of Business Psychology, 25, 211-223.

History of the mba. (2012, June 22). Retrieved from http://www.topmba.com/why$\mathrm{mba} /$ history-mba-mba-friday-facts

History of the University of Missouri. (n.d.). Retrieved August 14, 2016, from www.missouri.edu

Hobson, C. J., Strupeck, D., Griffin, A., Szostek, J., \& Rominger, A. S. (2014, July 01). Teaching MBA Students Teamwork and Team Leadership Skills: An Empirical Evaluation of a Classroom Educational Program. American Journal of Business Education, 7(3), 191-212.

Holton, E.L, (1992). Teaching going-to-work skills - a missing link in career development. Journal of Career Planning \& Employment, 52(3): 46-51. 
Holton, E. L., Russell, C. J., (1997). The relationship of anticipation to newcomer socialization processes and outcomes: A pilot study, Journal of Occupational and Organizational Psychology, 70, 163-172. Available from ProQuest. (199340193).

Howe, N. \& Strauss, W. (2000). Millenials Rising:The Next Generation. New York: Vintage Books.

Isen, A. M. (2000). Positive affect on decision-making. In M.Lewis \& J.M. Haviland-Jones (Eds.), Handbook of Emotions, (2 ${ }^{\text {nd }}$ ed., 417-435). New York:Guilford Press.

Jusoh, M., Simun, M., Chong, S.C. (2011). Expectation gaps, job satisfaction, and organizational commitment of recent graduates. Roles of graduates, higher learning institutions and employers. Education + Training, 53(6), 515-530.

Kane, K.F. (1993). MBAs:A recruiter’s eye view. Business Horizons, 36, 65-71.

Kanfer, R., Wanberg, C.R., Kantrowitz, T.M. (2001). Job search and employment:A personality-motivational analysis and meta-analytic review. Journal of Applied Psychology, 86, 837-855.

Kay, K. (2010). 21st century skills: Why they matter, what they are, and how we get there. In J. Bellanca \& R. Brandt (Eds.), 21st century skills: Rethinking how students learn (xiii-xxix). Bloomington, IN: Solution Tree Press.

Kedia, B. L., \& Harveston, P. D. (1998, July 01). Transformation of MBA Programs: Meeting the Challenge of International Competition. Journal of World Business, 33(2), 203-228.

Kelley, S. P. (2015). Developing millennials recruiting, retaining, encouraging the new generation. The NonProfit Times, 20-21.

Kereluik, K., Mishra, P., Fahnoe, C., \& Terry, L. . (2013). What knowledge is of most worth: Teacher knowledge for 21st century learning. Journal of Digital Learning in Teacher Education, 29(4), 127-140.

Kirschner, P. A., \& Van Merrienboer, J. J. (2013). Do Learners Really Know Best? Urban Legends in Education. Educational Psychologist, 48(3), 169-183. doi:10.1080/00461520.2013.804395

Kitroeff, N. (2014, November 11). Mba programs best business schools 2014: Duke tops full-time mba list, harvard slips. Bloomberg Businessweek.

Kohler, F. W. (1993). Designing a comprehensive and sustainable innovation by blending two different approaches to school reform. Education and Treatment of Children, 16(4), 382-400. 
Kuhnert, K.W. (1994). Transforming leadership: Developing people through delegation. In B. Bass \& B. Avolio (Eds.), Improving organizational effectiveness through transformational leadership, pp. 10-25, by Thousand Oaks, CA: Sage.

Lancaster, L.C. \& Stillman, D. (2002). When Generations Collide Who They Are. Why They Clash, How to Solve the Generational Puzzle at Work: New York: Harper Business.

Larson, L. C., \& Miller, T.N. (2011). 21st century skills: Prepare students for the future. Kappa Delta Pi Record, 47(3), 121-123.

Lavelle, L. (2012, June 22). Mba career trends. Retrieved from www.topmba.com

Lee, S.S., Hung, D. (2012). Is there an instructional framework for $21^{\text {st }}$ century learning? Creative Education, 3(4), 461-470.

Lent, R. W., Brown, S. D., \& Hackett, G. (1994). Toward a unifying social cognitive theory of career and academic interest, choice, and performance. Journal of Vocational Behavior, 45, 79-122.

Levi, D. (2014). Group dynamics for teams (4th ed.) Thousand Oaks, CA: Sage.

Lunenburg, F. (2012). Organizational structure: Mintzberg's framework. International Journal of Scholarly, Academic, Intellectual Diversity. 14(1).

McFadden, K. L., Jansen, B., \& Towell, E. R. (1999). Building OM Curriculum for the new millennium:Industry perceptions. Mid-American Journal of Business, 14(2), 37-45.

McTighe, J., \& Seif, E. (2010). An implementation framework to support 21st century skills. In J. Bellanca \& R. Brandt (Eds.), 21st century skills: Rethinking how students learn (pp. xiii-xxix). Bloomington, IN: Solution Tree Press.

Merriam, S.B. (2009). Qualitative research: A guide to design and implementation. Hoboken, NJ: Jossey-Bass.

Merriam, S. B., \& Bierema, L. L. (2014). Adult learning: Linking theory and practice. San Francisco, CA: Jossey-Bass John Wiley \& Sons.

Mintzberg, H. (2005). The power game and the players. In J. Sharfritz, J. Ott, \& Y. Jang (Eds). Classics of organizational theory (pp. 219-230). (Reprinted from Power in and around organizations, pp. 22-30, 1983, Upper Saddle River, NJ: Prentice-Hall)

Mintzberg, H. (2005). The five basic parts of the organization. In J. Sharfritz, J. Ott, \& Y. Jang (Eds). Classics of organizational theory (pp. 219-230). (Reprinted from The structure of organizations: A synthesis of research, pp. 18-34, 1979, Upper Saddle River, NJ: Prentice-Hall) 
Montgomery, D. B., \& Ramus, C. A. (2003). Corporate social responsibility reputation effects on mba job choice. Research Paper Series Stanford Graduate School of Business,

Muja, N., \& Appelbaum, S. H. (2012). Cognitive and affective process underlying career change. Career Development International, 17(7), 684-701. doi:10.1108/13620431211283814

Murray, N.D. (1997). Welcome to the future: The millennial generation. Journal of Career Planning \& Employment, 57(3): 36-42

(n.d.). Retrieved July 07, 2016, from http://www.merriamwebster.com/dictionary/credential

(n.d.). Retrieved January 23, 2017, from www.dictionary.com

Neeley, P., \& Tucker, J. (2012). An examination of the decision making process for selecting simulations for an online MBA program. Education + Training 56(2), 128138. doi:10.1108/004009113113044788.

Northouse, P. G. (2013). Leadership: theory and practice (6th ed.). Los Angeles, CA: Sage.

O'Connor, A., \& Raile, A. N. W. (2015). Millennials' "get a "real job"':exploring generational shifts in the colloquialism's characteristics and meanings. Management Communication Quarterly, 29(2), 276-290. doi: 10:1177/0893318915580153

Patton, M. Q. (2008). Utilization-focused evaluation (4th ed.). Thousand Oaks, CA: SAGE Publications, Inc.

Partnership for 21st Century Skills. (2011, March). Framework for 21st century learning. Washington, DC: Retrieved from Partnership for 21 st century skills website: http://www.p21.org/storage/documents/1._p21_framework_2-pager.pdf

P21 Framework Definitions. (2015, May). Retrieved July 31, 2016, from http://www.p21.org/storage/documents/docs/P21_Framework_Definitions New Lo go_2015.pd

Patton, M. Q. (2008). Utilization-focused evaluation (4th ed.). Thousand Oaks, CA: SAGE Publications, Inc.

Pearlman, B. (2010). Designing new learning environments to support 21 st century skills. In J. Bellanca \& R. Brandt (Eds.), 21st century skills: Rethinking how students learn (pp. 117-148). Bloomington, IN: Solution Tree Press. 
Perception. (n.d.). Dictionary.com Unabridged. Retrieved January 3, 2017 from Dictionary.com website http://www.dictionary.com/browse/credentials

Pink, D. (2009). Drive: The surprising truth about what motivates us. New York, NY: Riverhead books.

Post-Graduation Data. (2015, May). Retrieved July 07, 2016, from nwmissouri.edu

Preskill, S., \& Brookfield, S. D. (2009). Learning as a way of leading: Lessons from the struggle for social justice. San Francisco, CA: Jossey-Bass. (Selected readings)

President Obama, Address to the Joint Session of Congress, February 24, 2009.

Porter, L., \& McKibbin, L. (1988). Management Education and Deveopment:Drift or Thrust into the $21^{\text {st }}$ Century?, McGraw-Hill, New York, NY.

Reynolds, J. (2006). Learning-centered learning: A mindset shift for educators. Inquiry, $11(1), 55-64$.

Richardson, W. (2010). Navigating social networks as learning tools. In J. Bellanca \& R. Brandt (Eds.), 21st century skills: Rethinking how students learn (pp. 285-304). Bloomington, IN: Solution Tree Press.

Robinson, K., \& Aronica, L. (2015). Creative Schools: The grassroots revolution that's transforming education. New York, NY: Viking.

Saks, A., (2005). Multiple predictors and criteria of job search success. Journal of Vocational Behavior, 68, 400-415. doi:10.1006/jvbe.2005.10.001.

Saks, A., \& Ashforth, B. (2000). Change in job search behaviors and employment outcomes. Journal of Vocational Behavior, 56, 277-287. doi:10.1006/jvbe.1999.1714.

Sewell, P., \& Pool, L.D. (2010). Moving from conceptual ambiguity to operational clarity: employability, enterprise and entrepreneurship in higher education. Education + Training, 52(1), 89-94.

Shein, E. H., (1964). How to break in the college graduate. Harvard Business Review, 42, 68-76.

Shaari, I., \& Lee, S.S. (2012). Building relationships between schools and communities' agencies:Crafting a programmatic proposal. Creative Education, 3(3), 362-368.

Shelley, K., (1994). The more job openings-even more entrants: the outlook for college graduates 1992-2005. eOccupational Quarterly, Summer 1994, 4-9.

Skill. (n.d.). Dictionary.com Unabridged. Retrieved January 3, 2017 from Dictionary.com website http://www.dictionary.com/browse/credentials 
Song, Z., Wanberg, C., Niu, X., \& Xie, Y. (2006). Action-state orientation and the theory of planned behavior: A study of job search in China. Journal of Vocational Behavior $68,490-503$.

State and County Quick Facts. (2015, July 1). Retrieved July 7, 2016.

Strange, C.C. Constructions of student development across the generations, (2004). In Serving the Millennial Generation. New Directions in Student Services. San Francisco, CA: Jossey Bass, 106: 47-58.

Schwahn, C., \& McGarvey, B. (2012) Inevitable: Mass customized learning: Learning in the age of empowerment (New Edition). Kentucky: CreateSpace Independent Publishing Platform.

Unluer, S. (2012). Being an Insider Researcher While Conducting Case Study Research. The Qualitative Report, 17(58), 1-14. Retrieved April 3, 2016, from http://www.nova.edu/ssss/QR/QR17.unluer.pdf

Uyeno, J. (n.d.). What is a Bachelor of Science in Business Administration. Retrieved June 16, 2016, from www.ehow.com

Van Hooft, E., Born, M., Taris, T., Van Der Flier, H., Blonk, R., (2004). Predictors of job search behavior among employed and unemployed people. Personnel Psychology, 57, 25-59.

Van Hooft, E. A. J., Born, M. P., Taris, T. W., \& Van Der Flier, H. (2005). Predictors and outcomes of job search behavior: The moderating effects of gender and family situation. Journal of Vocational Behavior, 67, 133-152.

Van Hooft, E. A. J., Born, M. P., Taris, T. W., Van Der Flier, H., \& Blonk, R. W. B. (2004b). Predictors of job search behavior among employed and unemployed people. Personnel Psychology, 57, 25-59.

Van Hooft, E. A. J., Born, M. P., Taris, T. W., \& Van Der Flier, H. (2004a). Job search and the theory of planned behavior: Minority-majority group differences in The Netherlands. Journal of Vocational Behavior, 65, 366-390.

Veddar, R., Denhart, C., \& Robe, J. Center for College Affordability and Productivity, (2013). Why are recent college graduates underemployed? university enrollment and labor-market realities.

Wagner, T. (2012) Creating Innovators: The making of young people who will change the world. New York: Scribner. 
Wanberg, R.C., Hough, L.M., Song, Z. Predictive validity of a multidisciplinary model of reemployment success, (2002). Journal of Applied Psychology (87). 1100-1120.

Wanberg, C. R., Glomb, T. M., Song, Z., \& Sorenson, S. (2005). Job search persistence during unemployment: A 10-wave longitudinal study. Journal of Applied Psychology, 90, 411-430.

Werbel, J. (2000). Relationships among career exploration, job search intensity, and job search effectiveness in graduating college students. Journal of Vocational Behavior, 57, 379-394. doi: 10.1006/jvbe.2000.1746

What's the difference between skills and competencies? (2016, January 5). Retrieved July 06, 2016, from https://www.talentguard.com/whats-the-difference-between-skillsand-competencies/

Wiggins, G. (1990). The case for authentic assessment. Practical Assessment, Research, and Evaluation, 2(2), from http://pateonline.net

Woodard, D.B., Jr. Love, P. \& Komives, S.R. (2000). Students of new millennium. In Leadership and Management Issues for a New Century. San Francisco, CA: Jossey Bass, 92: 35-47.

Wong, D.B., (2010). Unemployed or unemployable. Retrieved July 5, 2016, from http://www.malyasiantoday.com.my/node/1726

Zabid, A., \& Ling, C. (2003). Malaysian Employer Perceptions About Local and Foreign MBA Graduates. Journal of Education for Business, 79(2), 111-117. doi:10.1080/08832320309599098

Zikic, J., \& Saks, A. (2009). Job search and social cognitive theory:the role of careerrelevant activities. Journal of Vocational Behavior, 74(1), 117-127. doi: doi:10.1016/j.jvb.2008.11.001 


\section{SECTION SIX}

\section{SCHOLARLY PRACTITIONER REFLECTION}

\section{Introduction}

The main reason I decided to pursue a doctorate in education was to help as many adults as possible achieve their educational goals and secure a rewarding career. Most importantly, to support the educational goals of minority and first-generation college students. When I re-read my admission essay, I was astounded that I have accomplished what I set out to do and aspire to accomplish for the remainder of my career.

Most people in the United States work for 40-50 years. Within the 40-50-year time span, they will change jobs several times, perhaps change fields, thus will need to be trained and re-trained. Think of all the changes in technology alone that occur on a regular basis; thus, a need for training. Adult learning is a necessity in order for adults to be highly skilled and competitive, to keep up with the changing demands of the workforce, secure jobs and promotions.

\section{Dissertation Influenced Practice as an Educational Leader}

My role as an educational leader is in the classroom with the example and standards I set for my students and the culture of learning, inclusion and ethical practice that I encourage and regulate. As a leader in the classroom with undergraduate and graduate business students ( $80 \%$ male), I must be able to regularly reframe, embrace and respond to diversity, ethics and privilege, and set a positive productive example of professional practice. A prevalent theme from my end of course surveys is summarized by one student's comment, "she cares about me and she really makes me think." 


\section{Culture of Inclusion and Ethical Practice}

As a leader in the classroom, I am a crucial source of ethical guidance and moral development (Mihelic, Lipicnik \& Tekavcic, 2010). Being a teaching professor/instructor in the College of Business, I am developing future business leaders and their understanding that market success and ethical leadership go hand in hand (Mihelic, Lipicnik \& Tekavcic, 2010). My educational leadership encourages their understanding and ability to practice asking insightful questions to make the students think, reframe, and refine their communication and critical thinking skills. As a leader, I want to be perceived as ethical and people-focused and show that I care about people, respect people, develop people, and treat people right. I aspire to have others view me as approachable, open and inclusive.

Diversity stems from differences in demographic, psychological, and organizational characteristics (Levi, 2014). As a leader in the classroom, I strive to create a psychologically safe team environment that encourages communication and collaboration. Along with diversity, is privilege, where one group has something of value that is denied to others because of the group one belongs to (Johnson, 2006). There are students that economically must work or participate in sports to fulfill their scholarship obligations while managing their academic responsibilities. It is challenging for these students to have ample time for their studies. Understanding the components of privilege and the impact privilege brings to the skills and competencies students exhibit in the classroom and how I as a leader can level the impact of privilege helps my students to be more successful.

I strive as a leader to be open, approachable and inclusive (Johnson, 2006). Fostering a successful culture of learning in the classroom where students are comfortable expressing their points of view, with an understanding of trust, commitment and mutual 
respect and accountability (Levi, 2014). It is the responsibility of educational leaders to create learning environments that foster respect, tolerance and intercultural understanding (Lopez, 2010).

\section{Managing Change}

I am reminded of the role the leader plays in change efforts. Leaders are called to manage change (Acker, 2006; Mihelic, Lipnicnik, \& Tekavcic, 2010). Transformational leadership describes how leaders initiate, develop, and carry out changes in organizations (Northouse, 2013). Transformational leadership has a strong emphasis on leaders and followers and their needs, values, and morals. A leader who manages change can inspire and motivate followers towards a common goal (Marsh, 2011). Collective vision, clear responsibilities, priorities, extensive communication and leaders that recognize the need for change are all critical to successful growth (Bolman \& Gallos, 2011; López, 2003; Kivel, 2000; Mihelic, Lipnicnik, \& Tekavcic, 2010; Marsh, 2010; Perrow, 1973).

As a leader, I strive to have a keen perception and a positive influence over the culture of my organization. I think regular assessments of the culture and feedback from the internal and external stakeholders will help make sure the culture is aligned with the organization's mission, vision, and strategic goals and tactics. Culture is a set of understandings a group share in common (Kivel, 2000). It includes their shared values and beliefs, symbols, and the embodiment of these meanings into material objects and ritualized practices. Signs of culture include rituals, stories, humor, jargon, physical arrangements, and formal structures and policies. (Shafritz, Ott \& Jang, 2005). Cultural forms provide important clues to what employees are thinking, believing, and doing (Bolman \& Deal, 2008). An understanding of the patterns that link signs of culture together will also bring to 
light the inner workings of the organization, the harmony, webs of ambiguity, paradox, contradiction, and sometimes bitter conflicts between groups. All are important to help leaders determine how to break down the barriers that prevent organizations from achieving their goals (Shafritz, Ott \& Jang, 2005). Culture is transmitted to those new to an organization or "the way we do things around here" as culture anchors an organization's identity and sense of self toward its goals (Bolman \& Deal, 2008). Architecture, interior décor, and dress are all powerful cultural clues (Trice \& Beyer, 1993).

\section{Team Building and Communication}

Communication is crucial in team building, and the leader sets the example for communication, discussion, and input. A trusting environment is built among the team members, when ideas and collaboration are shared, everyone feels included and valued and trusting relationships were built. Levi (2013) noted, "Team meetings operate more effectively if a facilitator structures the communication" (p. 117). By definition, teams work toward shared goals (Levi, 2013). Thus, cooperation is a vital feature in functioning teams (Levi, 2013). When team members pursue individual goals over team goals or when they compete against other members, the result is poor team performance (Levi, 2013; Nellis, 2012).

My leadership should set an example and be a positive role model of behavior and ethical communication to set the tone for the organization. Leaders have an ethical obligation to "create learning environments that fosters respect, tolerance, and intercultural understanding" (López, 2003, p. 71). An effective team should maintain an open, collaborative and trusting communication climate with a commitment to the goals of the team and organization (Lencioni, 2002). The team leader can facilitate an open climate by 
focusing conversations on issues, not on individual behaviors. The leader should ask openended and clarifying questions, and promote and manage healthy conflict as a way of organizing discussions around specific issues (Lencioni, 2002; Levi, 2013).

\section{Dissertation Process Influenced as a Scholar}

A scholar is a person who is constantly learning, a lifetime learner. The dissertation process has influenced me as a scholar to consistently be looking for better, more effective ways to inspire my students to learn. One of the most valuable semesters of the Educational Leadership and Policy Analysis program was the semester when we studied Adult Learning. Adults want to know how and why and apply what they have learned to a practical setting, to put what they learned into practice.

Fully utilizing my strengths of Positivity, Includer, Empathy, Individualization and Arranger, it is my goal to create the context where adults learn, a learning culture, a learning environment and organization. My Positivity and Arranger strengths help me as a leader to set the tone and expectations for the group, team and organization. It is up to the leader to build a team to gather feedback and reflect on how the team is functioning and creating a positive learning environment (Gill, 2009; Lencioni, 2002). Merriam (2014) states that adults want to learn in a trusting, inclusive, positive, open environment. Adults want to be respected for the experience they have on their jobs, with their families, and in their communities. They want to incorporate their new learning into their prior learning (Mandell \& Herman, 2009). A greater life experience provides a deeper well from which to draw on and reflect to engage learners (Taylor, 2009). As a leader, I want to create and sustain an open trusting learning environment for adult learners (Trevino, Brown \& Hartman, 2003). It is an environment where adults have a sense of involvement and belonging, where all 
perspectives are respected (Preskill \& Brookfield, 2009). Influencing scholarship occurs when a classroom becomes a community (Bruffee, 1999).

My Includer and Individualization strengths help me to understand that adult learners want to trust the group and be comfortable expressing their point of view, sharing their experiences, challenges, frustrations, and reflections. The leader encourages the climate that allows the expression of ideas, thoughts, and points of view (Preskill \& Brookfield, 2009). Fostering trusting relationships between learners and the teacher is the type of environment I want to create to help adults learn (Taylor, 2009).

Additionally, as a leader, in an adult learning environment, I want to create and sustain an environment where learners can gather feedback and reflect (Gill, 2009). Learning is change and as adults, we learn from a dialogue-centered approach with time for questions and answers and reflection. Critical thinking is also a component of adult learning where adults can check their assumptions and change their perspective based upon evidence (Merriam \& Bierema, 2014).

When I think about being a change agent in the context of adult learning, I reflect on the video about the evolution of the Pixar organization. Within the Pixar organization the goal is to create, acquire and transfer knowledge to encourage a learning organization. As a change agent, and a leader, I want to promote an environment where learners create, acquire and transfer knowledge. It is a supportive environment, where teams collaborate and share ideas, failures are recognized and celebrated and there is an error recovery process. Failures are the output of a person or group taking a risk and learning from the results to move forward and make changes to produce a success (Lencioni, 2002). Mandell \& Herman (2009) suggest that learning is change, thus as a change agent, I want to facilitate learning to 
promote an environment of change. My strengths of Individualization and Empathy help me as a leader to manage a learning environment where adults are recognized and respected for their contributions.

Adults learn about the process of change by challenging beliefs and assumptions or using "double-loop" learning (Argyris, 1977). They ask questions and want to know how, what and why (Gill, 2009). According to Preskill and Brookfield (2009), changes are made when questions are asked as in the Critical Incident Questionnaire. This questionnaire provides the framework to support and encourage openness by asking when the learners were the most engaged, distant, affirming, helpful, surprised and confused (Preskill \& Brookfield, 2009).

As a change agent leader, I want to determine, what's going on inside the student's heads and how can I get in there and change what is going on (Bruffee, 1999). The change agent leader creates an environment fostering trusting relationships between learners and the teacher through skillful classroom collaboration and the power of conversation (Taylor, 2009).

As a leader in an adult learning organization, I think building trust and respect for adult learner's experience on the job, with their family and community, along with prior learning experience are essential components to building whole organization learning. A learning organization is a changing and thriving organization. "If you continue to do the things the way you've been doing them, you'll continue to get the results you've been getting" (Gill, 2009, p. 1). A leader in adult learning is asking what works, what doesn't and why (Gill, 2009). Utilizing my strengths of Positivity, Includer, Empathy, 
Individualization and Arranger, to build a trusting, respectful adult learning environment where questions are asked and answered will lead to learning and change.

\section{Summary}

The changes in my leadership practice as a result of what I learned in the Educational Leadership and Policy Analysis (ELPA) Program are multi-faceted. First, the readings and discussion on teaming by Lencioni (2000), Mihelic, Lipicnik, \& Tekavcic (2010), Marsh (2010), and Nellis (2012) inspired me to develop a presentation for my students on how to effectively work as a team. I also changed the course content and placed a stronger emphasis on the team project because of what I learned about teaming. Secondly, the readings and discussion on diversity, power, and privilege by Acker (1992), Johnson (2006), López (2003), March (1966) influenced me to change the class participation process and call on students to answer questions from the class list rather than student's answering on their own initiative. This provides the opportunity for all to be included and reduces the advantage of privilege and empowers all students. Additionally, the discussion on ethics, diversity and power helped me to reframe and access situations from the perspective of the student or the group challenged by ethics, diversity, privilege or power. The readings on organizational analysis, specifically Bolman \& Deal (2008) influenced me to evaluate decisions and changes using each of the four frames. Thus, I think making more comprehensive, inclusive decisions.

In summary, the most influential result of my learning in the ELPA program is from Trevino, Brown \& Hartman (2003). Their research stated an ethical environment is one where people are cared about, there is a people focus, and people are respected and developed. Finally, from Mihelic, Lipicnik \& Tekavcic, 2010, as an ethical leader, I want to 
be someone who puts values into action, and demonstrates integrity with a high level of trust and respect. I want to be viewed as a leader that embraces openness, inclusion, diversity, integrity, a role model for ethical behavior and conduct, building strong teams and accomplishing goals and objectives. 


\title{
Appendix A
}

\section{CASE STUDY INFORMED CONSENT}

\author{
Case Study: \\ I will research the perceptions of Master in Business Administration (MBA) students and \\ recent graduates with those of employers of recent MBA graduates regarding the skills, \\ competencies, and experiences needed to be successful in their new graduate jobs.
}

\section{Principal investigator:}

Jan Whitlow

\section{Institute:}

University of Missouri Columbia

\section{Introduction:}

You are invited to participate in a survey to better understand the skills, competencies, and experiences needed to be successful in an MBA new graduate job.

\section{Background information:}

This is research for a dissertation within the Educational Doctorate Program through the University of Missouri-Columbia and Northwest Missouri State University.

\section{Purpose of this research study:}

The problem under investigation is bounded by a large Midwestern University's MBA program graduates and their skills and competencies needed for success in their postgraduate jobs. According to Berdan (2012), a cross-section of the opinions of business leaders, civil servants and academics the skills list in order of importance included communication skills, resilience, global mindset, character, quantitative, analytical and strategic thinking skills. The purpose of this study is to discover the possible gap in new knowledge between employers' perceptions of MBA graduates' skills and competencies, whether recent MBA graduates themselves believe they possess the skills and whether the curriculum provides the opportunity for students to develop the skills to be successful in their post-graduate position. The study will also examine the successes and challenges in the learning environment, the need for curriculum and instructional changes, learning platforms and activities to provide the opportunity and environment for students to develop the skills employers value.

\section{Procedures:}

A variety of qualitative research methods will be used to identify the perceptions of the skills and competencies recent MBA graduates need to be successful in their postgraduation jobs.

Surveys will be conducted with managers employing recent MBA graduates. Online surveys will be completed by MBA students and recent MBA graduates to identify the skills and competencies they perceive as necessary to be successful in their new graduate position. 
Surveys will be conducted until the saturation point is determined.

\section{Possible risks or benefits:}

There is no risk involved in this study except your valuable time. This research has the potential of having an impact on MBA curriculum and educational practices.

\section{Right of refusal to participate and withdrawal:}

You are free to choose to participate in the study. You may also withdraw from the study.

You may also refuse to answer some or all the questions, if you do not feel comfortable with the questions.

\section{Confidentiality:}

Any information you provide will remain confidential. No one except the principal investigators will have access to it. Your name and identity will also not be disclosed at any time.

\section{Available Sources of Information:}

If you have further questions you may contact Dr. Carole Edmonds(cake@nwmissouri.edu), the researcher's advisor.

\section{AUTHORIZATION}

I have read and understand this consent form, and I volunteer to participate in this research study. I understand that I will receive a copy of this form. I voluntarily choose to participate, but I understand that my consent does not take away any legal rights in the case of negligence or other legal fault of anyone who is involved in this study. I further understand that nothing in this consent form is intended to replace any applicable Federal, state, or local laws.

If you have any further questions I can answer, please contact me.

Jan Whitlow

816.405 .0003

jmht8b@mail.missouri.edu

You may also contact the Campus Institutional Review Board if you have questions about your rights, concerns, complaints or comments as a research participant. You can contact the Campus Institutional Review Board directly by telephone or email to voice or solicit any concerns, questions, input or complaints about the research study.

483 McReynolds Hall

Columbia, MO 65211

573-882-9585

E-Mail: umcresearchcirb@missouri.edu

Website: http://www.research.missouri.edu/cirb/index.htm 


\section{Appendix B}

PERCEPTIONS OF MBA PREPARATION: NEW MASTER OF BUSINESS

ADMINISTRATION GRADUATES, THEIR EMPLOYERS, AND HIGHER

EDUCATION FACULTY

\section{Survey Questions}

Warm-up questions:

Employers of recent MBA graduates

How long have you worked with recent MBA graduates?

MBA Students

Did you have prior work experience after receiving your bachelor's degree?

What semester are you in your MBA program?

MBA new graduates

How long have you been in your recent graduate position?

Survey questions:

Employers of recent MBA graduates:

What are your perceptions of the skills, competencies and experiences recent graduates are lacking?

What are your perceptions of the strongest skills, competencies, and experiences of recent graduates?

What are your suggestions for higher education to help improve the skills, competencies and experiences of MBA graduates?

MBA students:

What are your perceptions of the skills, competencies and experiences that will help you to be successful in your post-graduation position?

What are your suggestions for higher education to help improve the skills, competencies and experiences of MBA graduates?

MBA recent graduates:

What are your perceptions of the skills, competencies and experiences that have helped you be successful in your post-graduation position?

What are your suggestions for higher education to help improve the skills, competencies and experiences of MBA graduates? 


\section{Closing question:}

What do you think should change about the MBA experience to better prepare graduates for the workforce? 


\section{References}

Acker, J. (2006). Inequality regimes gender, class, and race in organization. Gender \& Society, 20(4), 441-464. doi: DOI:10.1177/0891243206289499

Admissions. (n.d.). Retrieved October 23, 2016, from https://business.missouri.edu/programs-and-admissions/crosby$\underline{\mathrm{mba} / \text { academics/concentrations }}$

Advancing quality management education worldwide. (2015, July). Retrieved from www.aacsb.edu

Ajzen, I. (1991). The theory of planned behavior. Organizational Behavior and Human Decision Process, 50, 179-211.

Alsop, R. (2008). The trophy kids grow up: How the millennial generation is shaking up the workplace. San Francisco: Jossey- Bass.

Ancona, D., Malone, T., Orlikoswki, W., \& Senge, P. (2011). Leading Change. In HBR's 10 must reads on leadership (pp. 179-196). Boston, MA: Harvard Business Review Press. (Reprint R0702E, originally published February 2007)

Annual Earnings of Young Adults. (2016, May 01). Retrieved June 21, 2016, from http://nces.ed.gov/programs/coe/indicator_cba.asp

Argyris, C. (1977, Sept.-Oct.) Double loop learning in organizations. Harvard Business Review, pp. 115-125.

Bandura, A. (1986). Social foundations of thought and action: A social cognitive theory, Englewood Cliffs, NJ: Prentice Hall.

Berdan, S. N. (2012, February 04). Top Skills MBA Grads Need for Success. Retrieved March 30, 2016.

Blau, G. (1994). Testing a two-dimension measure of job search behavior. Organizational Behavior and Human Decision Process, 59, 288-312.

Bolman, L. G. \& Deal, T. E. (2008). Reframing organizations: Artistry, choice, and leadership (4th ed.). San Francisco, CA: Jossey-Bass.

Boyatzis, R.E., (2007). Competencies in the $21^{\text {st }}$ century. Journal of Management Development, 27(1), 5-12.

Boyatzis, R.E., (2008). A 20-year view of trying to develop emotional, social and cognitive intelligence competencies in graduate management education. Journal of Management Development, 27(1), 92-108. 
Boyatzis, R.E., \& Sokol, M. (1982). A pilot project to access the feasibility of assessing skills and person characteristics of students in collegiate business programs, report to the AACSB, St. Louis, MO.

Brinkerhoff, C. (2016, April 8). MBA Program Strategic Plan. Lecture presented at MBA Strategic Plan in College of Business, Columbia.

Brinkerhoff, C. (2016, July 27). Organizational and leadership analysis [E-mail to the author].

Brown, D. J., Cober, R. T., Kane, K., Levy, P. E., \& Shalhoop, J. (2006). Proactive personality and the successful job search: a field investigation with college graduates. Journal of Applied Psychology, 91(3), 717-726. doi: 10.103700219010.91.3.717.

Bruce, G. D. (2010). Exploring the value of MBA degrees: Students' experiences in fulltime, part-time and executive MBA programs. Journal of Education for Business, 85, 38-44. DOI: 10.1080/08832320903217648

Bruffee, K.A. (1999). Collaborative learning: Higher education, interdependence, and the authority of knowledge. Baltimore, MD: Johns Hopkins University Press. (Selected readings)

Buckley, M. R., Peach, E. B., Weitzel, W. (1989). Are collegiate business programs adequately preparing students for the business world? Journal of Education for Business, 45(3), 101-105.

Casner-Lotto, J. \& Barrington, L. (2006). Are they really ready to work? Employers' perspectives on the basic knowledge and applied skills of new entrants to the $21^{\text {st }}$ century U.S. workforce, p.9: Conference Board, Corporate Voices for Working Families, Partnership for $21^{\text {st }}$ Century Sills, and Society for Human Resource Management.

Columbia Missouri Household Income. (2014). Retrieved April 03, 2016, from http://www.deptofnumbers.com/income/missouri/columbia/

Competencies. (n.d.). Dictionary.com Unabridged. Retrieved January 3, 2017 from Dictionary.com website http://www.dictionary.com/browse/credentials

Coomes, M.D., DeBard, R. (Eds.) (2004). Serving the Millennial Generation. New Directions in Student Services. San Franciso, CA: Jossey Bass.

Cote, S., Saks, A. \& Zikic, J. (2006). Trait affect and job search outcomes. Journal of Vocational Behavior, 68, 233-252. doi:10.1016/j.jvb.2005.08.001. 
Credentials. (n.d.). Dictionary.com Unabridged. Retrieved January 3, 2017 from Dictionary.com website http://www.dictionary.com/browse/credentials

Curriculum. (n.d.). Retrieved October 23, 2016, from https://business.missouri.edu/programs-and-admissions/crosby$\underline{\mathrm{mba} / \text { academics/concentrations }}$

Creswell, J.W. (2009). Research design: Quantitative, qualitative, and mixed methods approaches (3rd ed.). Thousand Oaks, CA: Sage.

Crosby MBA. (n.d.). Retrieved June 14, 2016.

da Motta Veiga, S. P., \& Turban, D. B. (2014). Are affect and perceived stress detrimental or beneficial to job seekers? the role of learning goal orientation in job search selfregulation. Organizational Behavior and Human Decision Process, 125, 193-203. doi: 10.1016/j.obhdp.2014.09.007

Darling-Hammond, L., Rustique-Forrester, E., \& Pecheone, R. (2005). Multiple measures approaches to high school graduation. Stanford, CA:School Redesign Network at Stanford University.

Darling-Hammond, L., Snyder, J.. (2000). Authentic assessment of teaching in context. Teaching and Teacher Education, 12, 523-545.

Dede, C. (2010). Comparing frameworks for 21 st century skills. In J. Bellanca \& R. Brandt (Eds.), 21st century skills: Rethinking how students learn (pp. 51-76). Bloomington, IN: Solution Tree Press.

DiMartino, J., \& Castaneda, A. (2007, April 01). Assessing Applied, The Carnegie unit, awarding course credit for seat time, is working against efforts to teach and test 21 st century workforce skills. Educational Leadership, 38-42.

Ding, H., \& Ding, X. (2013). 360-degree rhetorical analysis of job hunting: A four-part, multimodal project. Business Communications Quarterly, 76(2), 239-248. doi: $10.1177 / 1080569912475207$

Dougherty, T., Dreher, G., \& Whitely, W. (1993). The mba as careerist:an analysis of early career job change. Journal of Management, 19(3), 535-548.

Drake, P., \& Heath, L. (2011). Practitioner research at doctoral level developing coherent research methodologies. (First ed., pp. 46-58). London, New York: Routledge.

Drucker, P. F. (2011). What Makes an Effective Executive. Boston, Massachusetts: Harvard Business Review Press, 23-36. 
Edmondson, A. C. (2012). Teaming: How organizations learn, innovate, and compete in the knowledge economy. San Francisco, CA: Jossey-Bass. (Selected readings)

Elam, C., Stratton, T., \& Gibson, D. (2007). Welcoming a new generation to college: The millennial students. Journal of College Admissions, Spring, 20-25. Retrieved from www.nacacnet.org

Employers Want Communication Skills in New Hires. (2014, August 7). Retrieved March 30, 2016, from http://www.mba.com/us/the-gmat-blog-hub/the-official-gmatblog/2014/aug/employers-want-communication-skills-in-new-hires.aspx

Ennis, R. H. (2002, June 20). A super-streamlined conception of critical thinking. Retrieved July 07, 2016, from www.criticalthinking.com

Enrollment Data. (2016, May). Retrieved July 07, 2016, from nwmissouri.edu

Epstein, J. (2010). "Going ahead with gainful employment”, Retrieved April 2, 2016, from http://www.insidehighered.com/news/2010/04/21/gainful

Epstein, M., \& Howes, P. (2008). Recruiting, retaining and managing the millennial generation. Selected readings 2008-Management of a practice [CD ROM]. New York: American Institute of Certified Public Accountants.

Feldman, D. (2007). The food's no good and they don't give us enough: Reflections on Mintzberg's critique of MBAeducation. Journal of Education for Business, 82, 217-220.

Feldman, D.C. (1976). A practical programme for employee socialization. Organizational Dynamics, 5, 65-80.

Fink, A. (2013). How to conduct surveys: A step by step guide. Thousand Oaks, CA: Sage Publications, Inc.

Forgas, J. P. (1995). Mood and judgement: The affect infusion model (AIM). Psychological Bulletin, 117, 39-66.

Framework for 21st Century Learning. (2007, July 23). Retrieved June 14, 2016, from www.21stcenturyskills.org

Gabric, D., \& McFadden, K. L. (2000). Student and Employer Perceptions of Desirable Entry-Level Operations Management Skills. Mid-American Journal of Business, 16(1), 51-59.

Garavan, T. N., Morley, M., (1997). The socialization of high-potential graduates into the organization initial expectations, experiences and outcomes, Journal of Managerial Psychology, 12(2), 118-137. Available from ProQuest. (215867067). 
Gault, J., Redington, J., \& Schlager, T. (2015). Undergraduate business internships and career success: Are they related? Unpublished manuscript, Available from ProQuest. (204412303).

Gill, S. J. (2009). Developing a learning culture in nonprofit organizations. Thousand Oaks, CA: Sage. (Selected readings).

Goffee, R., \& Jones, G. (2011). Why should anyone be led by you? In HBR's 10 must reads on leadership (pp. 79-95). Boston, MA: Harvard Business Review Press. (Reprint R00506, Originally published September 2000)

Goleman, D. (2011). What makes a leader? In HBR's 10 must reads on leadership (pp. 121). Boston, MA: Harvard Business Review Press. (Reprint R0401H, Originally published June 1996)

Gulikers, J.T., Bastiaens, T.J. and Kirschner, P.A. (2004), A five-dimensional framework for authentic assessment, Educational Technology Research and Development, Vol. 52 No. 3, pp. 67-85.

Graduate Management Admission Council. (2003a). Global MBA graduate

Graf, D. (1997). Critical success factors for community-based education. Mid-America Journal of Business, 12(2), 51-59.

Hammond, D.H., Hartman, S.J., Brown, R.A. (1996). The match between undergraduate academic instruction and actual field practices in production/operations management. Journal of Education for Business, 71(5), 263-266.

Harris, T.L., \& Hodges, R.E. (1995). The Literacy Dictionary The Vocabulary of Reading and Writing. Newark, DE: International Reading Association.

Heifetz, R. A., \& Laurie, D. L. (2011). The Work of Leadership. Harvard Business Review On Leadership, 57-79.

Heitkemper, M.R. (1998). Work-study experience of college graduates as it relates to the transition to work and job satisfaction. Unpublished academic dissertation, Gonzaga University, Spokane, WA.

Herman, J. (1997). Assessing new assessments: Do they measure up? Theory into Practice, 36(4), 196-204.

Hershatter, A., \& Epstein, M. (2010). Millennials and the world of work:an organizational and management perspective. Journal of Business Psychology, 25, 211-223. 
History of the mba. (2012, June 22). Retrieved from http:/www.topmba.com/why$\mathrm{mba} /$ history-mba-mba-friday-facts

History of the University of Missouri. (n.d.). Retrieved August 14, 2016, from www.missouri.edu

Hobson, C. J., Strupeck, D., Griffin, A., Szostek, J., \& Rominger, A. S. (2014, July 01). Teaching MBA Students Teamwork and Team Leadership Skills: An Empirical Evaluation of a Classroom Educational Program. American Journal of Business Education, 7(3), 191-212.

Holton, E.L, (1992). Teaching going-to-work skills - a missing link in career development. Journal of Career Planning \& Employment, 52(3): 46-51.

Holton, E. L., Russell, C. J., (1997). The relationship of anticipation to newcomer socialization processes and outcomes: A pilot study, Journal of Occupational and Organizational Psychology, 70, 163-172. Available from ProQuest. (199340193).

Howe, N. \& Strauss, W. (2000). Millenials Rising:The Next Generation. New York: Vintage Books.

Isen, A. M. (2000). Positive affect on decision-making. In M.Lewis \& J.M. Haviland-Jones (Eds.), Handbook of Emotions, (2 ${ }^{\text {nd }}$ ed., 417-435). New York:Guilford Press.

Johnson, A.G. (2006). Privilege, power, and difference. ( $2^{\text {nd }}$ ed., pp. 12-40). Boston:McGraw-Hill.

Jusoh, M., Simun, M., Chong, S.C. (2011). Expectation gaps, job satisfaction, and organizational commitment of recent graduates. Roles of graduates, higher learning institutions and employers. Education + Training, 53(6), 515-530.

Kane, K.F. (1993). MBAs:A recruiter's eye view. Business Horizons, 36, 65-71.

Kanfer, R., Wanberg, C.R., Kantrowitz, T.M. (2001). Job search and employment:A personality-motivational analysis and meta-analytic review. Journal of Applied Psychology, 86, 837-855.

Kay, K. (2010). 21st century skills: Why they matter, what they are, and how we get there. In J. Bellanca \& R. Brandt (Eds.), 21st century skills: Rethinking how students learn (xiii-xxix). Bloomington, IN: Solution Tree Press.

Kedia, B. L., \& Harveston, P. D. (1998, July 01). Transformation of MBA Programs: Meeting the Challenge of International Competition. Journal of World Business, 33(2), 203-228. 
Kelley, S. P. (2015). Developing millennials recruiting, retaining, encouraging the new generation. The NonProfit Times, 20-21.

Kereluik, K., Mishra, P., Fahnoe, C., \& Terry, L. . (2013). What knowledge is of most worth: Teacher knowledge for 21 st century learning. Journal of Digital Learning in Teacher Education, 29(4), 127-140.

Kivel, P., (2000). The culture of power. Uprooting Racism: How White People Can Work for Racial Justice.

Kirschner, P. A., \& Van Merrienboer, J. J. (2013). Do Learners Really Know Best? Urban Legends in Education. Educational Psychologist, 48(3), 169-183. doi:10.1080/00461520.2013.804395

Kitroeff, N. (2014, November 11). Mba programs best business schools 2014: Duke tops full-time mba list, harvard slips. Bloomberg Businessweek.

Kohler, F. W. (1993). Designing a comprehensive and sustainable innovation by blending two different approaches to school reform. Education and Treatment of Children, $16(4), 382-400$.

Kuhnert, K.W. (1994). Transforming leadership: Developing people through delegation. In B. Bass \& B. Avolio (Eds.), Improving organizational effectiveness through transformational leadership, pp. 10-25, by Thousand Oaks, CA: Sage.

Lancaster, L.C. \& Stillman, D. (2002). When Generations Collide Who They Are. Why They Clash, How to Solve the Generational Puzzle at Work: New York: Harper Business.

Larson, L. C., \& Miller, T.N. (2011). 21st century skills: Prepare students for the future. Kappa Delta Pi Record, 47(3), 121-123.

Lavelle, L. (2012, June 22). Mba career trends. Retrieved from www.topmba.com

Lee, S.S., Hung, D. (2012). Is there an instructional framework for $21^{\text {st }}$ century learning? Creative Education, 3(4), 461-470.

Lencioni, P. (2002). The five dysfunctions of a team: A leadership fable. San Francisco, CA: Jossey-Bass.

Lent, R. W., Brown, S. D., \& Hackett, G. (1994). Toward a unifying social cognitive theory of career and academic interest, choice, and performance. Journal of Vocational Behavior, 45, 79-122.

Levi, D. (2014). Group dynamics for teams (4th ed.) Thousand Oaks, CA: Sage. 
Lopez, G. (2003). The (racially neutral) politics of education: A critical race theory perspective. Educational Administrative Quarterly 2003 (39:68), 68-94. doi:10.1177/0013161X02239761

Lunenburg, F. (2012). Organizational structure: Mintzberg's framework. International Journal of Scholarly, Academic, Intellectual Diversity. 14(1).

Mandell, A., \& Herman, L. (2009). Mentoring: When learners make the learning. In J. Mezirow \& E. W. Taylor (Eds.), Transformative learning in practice: Insights from community, workplace, and higher education (pp. 78-88). San Francisco: CA: Jossey-Bass.

March, J.G. (2011). The power of power. In J.M. Shafritz, J.S. Ott, \& Y.S. Jang (Eds.), Classics of organizational theory (7th ed., pp. 307-319). Boston, MA: Wadsworth. (Reprinted from Varieties of political theory, pp. 39-70, by D. Easton, Ed., 1966, Englewood Cliffs, NJ: Prentice-Hall).

Marsh, F. (2010). High performance team: Building a business program with part-and fulltime faculty. Journal of Education for Business, 85, 187-197. Doi: 0883-2323

McFadden, K. L., Jansen, B., \& Towell, E. R. (1999). Building OM Curriculum for the new millennium:Industry perceptions. Mid-American Journal of Business, 14(2), 37-45.

McTighe, J., \& Seif, E. (2010). An implementation framework to support 21 st century skills. In J. Bellanca \& R. Brandt (Eds.), 21st century skills: Rethinking how students learn (pp. xiii-xxix). Bloomington, IN: Solution Tree Press.

Merriam, S.B. (2009). Qualitative research: A guide to design and implementation. Hoboken, NJ: Jossey-Bass.

Merriam, S. B., \& Bierema, L. L. (2014). Adult learning: Linking theory and practice. San Francisco, CA: Jossey-Bass John Wiley \& Sons.

Mihelic, K., Lipicnik, B., \& Tekavcic, M. (2010). Ethical Leadership. International Journal of Management and Information Systems, Fourth Quarter 2010(14:5), 31-41.

Mintzberg, H. (2005). The power game and the players. In J. Sharfritz, J. Ott, \& Y. Jang (Eds). Classics of organizational theory (pp. 219-230). (Reprinted from Power in and around organizations, pp. 22-30, 1983, Upper Saddle River, NJ: Prentice-Hall)

Mintzberg, H. (2005). The five basic parts of the organization. In J. Sharfritz, J. Ott, \& Y. Jang (Eds). Classics of organizational theory (pp. 219-230). (Reprinted from The structure of organizations: A synthesis of research, pp. 18-34, 1979, Upper Saddle River, NJ: Prentice-Hall) 
Montgomery, D. B., \& Ramus, C. A. (2003). Corporate social responsibility reputation effects on mba job choice. Research Paper Series Stanford Graduate School of Business,

Muja, N., \& Appelbaum, S. H. (2012). Cognitive and affective process underlying career change. Career Development International, 17(7), 684-701. doi:10.1108/13620431211283814

Murray, N.D. (1997). Welcome to the future: The millennial generation. Journal of Career Planning \& Employment, 57(3): 36-42

(n.d.). Retrieved July 07, 2016, from http://www.merriamwebster.com/dictionary/credential

(n.d.). Retrieved January 23, 2017, from www.dictionary.com

Neeley, P., \& Tucker, J. (2012). An examination of the decision making process for selecting simulations for an online MBA program. Education + Training 56(2), 128 138. doi:10.1108/004009113113044788.

Nellis, L. (2012). Maximizing the effectiveness of building teams in response to intervention implementation. Psychology in the Schools, 49(3), doi: 10.1002/pits. 21594

Northouse, P. G. (2013). Leadership: theory and practice (6th ed.). Los Angeles, CA: Sage.

O'Connor, A., \& Raile, A. N. W. (2015). Millennials' "get a "real job"':exploring generational shifts in the colloquialism's characteristics and meanings. Management Communication Quarterly, 29(2), 276-290. doi: 10:1177/0893318915580153

Patton, M. Q. (2008). Utilization-focused evaluation (4th ed.). Thousand Oaks, CA: SAGE Publications, Inc.

Partnership for 21st Century Skills. (2011, March). Framework for 21st century learning. Washington, DC: Retrieved from Partnership for 21st century skills website: http://www.p21.org/storage/documents/1._p21_framework_2-pager.pdf

P21 Framework Definitions. (2015, May). Retrieved July 31, 2016, from http://www.p21.org/storage/documents/docs/P21_Framework_Definitions_New_Lo go_2015.pd

Patton, M. Q. (2008). Utilization-focused evaluation (4th ed.). Thousand Oaks, CA: SAGE Publications, Inc. 
Pearlman, B. (2010). Designing new learning environments to support 21 st century skills. In J. Bellanca \& R. Brandt (Eds.), 21st century skills: Rethinking how students learn (pp. 117-148). Bloomington, IN: Solution Tree Press.

Perception. (n.d.). Dictionary.com Unabridged. Retrieved January 3, 2017 from Dictionary.com website http://www.dictionary.com/browse/credentials

Perrow, C. (1973). The short and glorious history of organizational theory. Organizational Dynamics, 73(3), 2-15.

Pink, D. (2009). Drive: The surprising truth about what motivates us. New York, NY: Riverhead books.

Post-Graduation Data. (2015, May). Retrieved July 07, 2016, from nwmissouri.edu

Preskill, S., \& Brookfield, S. D. (2009). Learning as a way of leading: Lessons from the struggle for social justice. San Francisco, CA: Jossey-Bass. (Selected readings)

President Obama, Address to the Joint Session of Congress, February 24, 2009.

Porter, L., \& McKibbin, L. (1988). Management Education and Deveopment:Drift or Thrust into the $21^{\text {st }}$ Century?, McGraw-Hill, New York, NY.

Reynolds, J. (2006). Learning-centered learning: A mindset shift for educators. Inquiry, $11(1), 55-64$.

Richardson, W. (2010). Navigating social networks as learning tools. In J. Bellanca \& R. Brandt (Eds.), 21st century skills: Rethinking how students learn (pp. 285-304). Bloomington, IN: Solution Tree Press.

Robinson, K., \& Aronica, L. (2015). Creative Schools: The grassroots revolution that's transforming education. New York, NY: Viking.

Saks, A., (2005). Multiple predictors and criteria of job search success. Journal of Vocational Behavior, 68, 400-415. doi:10.1006/jvbe.2005.10.001.

Saks, A., \& Ashforth, B. (2000). Change in job search behaviors and employment outcomes. Journal of Vocational Behavior, 56, 277-287. doi:10.1006/jvbe.1999.1714.

Sewell, P., \& Pool, L.D. (2010). Moving from conceptual ambiguity to operational clarity: employability, enterprise and entrepreneurship in higher education. Education + Training, 52(1), 89-94.

Shafritz, J. M., Ott, J. S., \& Jang, Y. S. (2005). Classics of organization theory. (6th ed., pp. 125-133). Boston, MA: Wadsworth. 
Shein, E. H., (1964). How to break in the college graduate. Harvard Business Review, 42, 68-76.

Shaari, I., \& Lee, S.S. (2012). Building relationships between schools and communities' agencies:Crafting a programmatic proposal. Creative Education, 3(3), 362-368.

Shelley, K., (1994). The more job openings-even more entrants: the outlook for college graduates 1992-2005. eOccupational Quarterly, Summer 1994, 4-9.

Skill. (n.d.). Dictionary.com Unabridged. Retrieved January 3, 2017 from Dictionary.com website http://www.dictionary.com/browse/credentials

Song, Z., Wanberg, C., Niu, X., \& Xie, Y. (2006). Action-state orientation and the theory of planned behavior: A study of job search in China. Journal of Vocational Behavior 68, 490-503.

State and County Quick Facts. (2015, July 1). Retrieved July 7, 2016.

Strange, C.C. Constructions of student development across the generations, (2004). In Serving the Millennial Generation. New Directions in Student Services. San Francisco, CA: Jossey Bass, 106: 47-58.

Schwahn, C., \& McGarvey, B. (2012) Inevitable: Mass customized learning: Learning in the age of empowerment (New Edition). Kentucky: CreateSpace Independent Publishing Platform.

Taylor, E. W. (2009). Fostering transformative learning. In J. Mezirow \& E. W. Taylor (Eds.), Transformative learning in practice: Insights from community, workplace, and higher education (pp. 3-17). San Francisco

Trice, H., Beyer, J (1993). Changing organizational culture. In Shafritz, J. M., Ott, J. S., \& Jang, Y. S. (2005). Classics of organization theory. (6th ed., pp. 383-392.) Boston, MA: Wadsworth.

(Reprinted from The cultures of work organization, (1993), pp. 393-428.

Unluer, S. (2012). Being an Insider Researcher While Conducting Case Study Research. The Qualitative Report, 17(58), 1-14. Retrieved April 3, 2016, from http://www.nova.edu/ssss/QR/QR17.unluer.pdf

Uyeno, J. (n.d.). What is a Bachelor of Science in Business Administration. Retrieved June 16, 2016, from www.ehow.com

Van Hooft, E., Born, M., Taris, T., Van Der Flier, H., Blonk, R., (2004). Predictors of job search behavior among employed and unemployed people. Personnel Psychology, $57,25-59$. 
Van Hooft, E. A. J., Born, M. P., Taris, T. W., \& Van Der Flier, H. (2005). Predictors and outcomes of job search behavior: The moderating effects of gender and family situation. Journal of Vocational Behavior, 67, 133-152.

Van Hooft, E. A. J., Born, M. P., Taris, T. W., Van Der Flier, H., \& Blonk, R. W. B. (2004b). Predictors of job search behavior among employed and unemployed people. Personnel Psychology, 57, 25-59.

Van Hooft, E. A. J., Born, M. P., Taris, T. W., \& Van Der Flier, H. (2004a). Job search and the theory of planned behavior: Minority-majority group differences in The Netherlands. Journal of Vocational Behavior, 65, 366-390.

Veddar, R., Denhart, C., \& Robe, J. Center for College Affordability and Productivity, (2013). Why are recent college graduates underemployed? university enrollment and labor-market realities.

Wagner, T. (2012) Creating Innovators: The making of young people who will change the world. New York: Scribner.

Wanberg, R.C., Hough, L.M., Song, Z. Predictive validity of a multidisciplinary model of reemployment success, (2002). Journal of Applied Psychology (87). 1100-1120.

Wanberg, C. R., Glomb, T. M., Song, Z., \& Sorenson, S. (2005). Job search persistence during unemployment: A 10-wave longitudinal study. Journal of Applied Psychology, 90, 411-430.

Werbel, J. (2000). Relationships among career exploration, job search intensity, and job search effectiveness in graduating college students. Journal of Vocational Behavior, 57, 379-394. doi: 10.1006/jvbe.2000.1746

What's the difference between skills and competencies? (2016, January 5). Retrieved July 06, 2016, from https://www.talentguard.com/whats-the-difference-between-skillsand-competencies/

Wiggins, G. (1990). The case for authentic assessment. Practical Assessment, Research, and Evaluation, 2(2), from http://pateonline.net

Woodard, D.B., Jr. Love, P. \& Komives, S.R. (2000). Students of new millennium. In Leadership and Management Issues for a New Century. San Francisco, CA: Jossey Bass, 92: 35-47.

Wong, D.B., (2010). Unemployed or unemployable. Retrieved July 5, 2016, from http://www.malyasiantoday.com.my/node/1726 
Zabid, A., \& Ling, C. (2003). Malaysian Employer Perceptions About Local and Foreign MBA Graduates. Journal of Education for Business, 79(2), 111-117. doi:10.1080/08832320309599098

Zikic, J., \& Saks, A. (2009). Job search and social cognitive theory:the role of careerrelevant activities. Journal of Vocational Behavior, 74(1), 117-127. doi: doi:10.1016/j.jvb.2008.11.001 


\section{VITAE}

Jan Whitlow earned a Bachelor of Science in Business Administration degree from the University of Missouri Columbia with an emphasis in Marketing and a Master of Business Administration degree from Avila University. Her career in business includes positions with Hallmark Cards, Inc. in product development, marketing communications, and sales. Additionally, she has experience in healthcare marketing, fundraising, grant writing, and community education with Saint Luke's Foundation and Saint Luke's Health System. Experience in education includes teaching Marketing courses in the undergraduate and graduate programs for the University of Missouri Columbia, Northwest Missouri State University, and Park University.

She plans to utilize her expertise in Marketing and Education, and passion for helping students achieve to their potential by developing their skills, competencies, and experiences. 